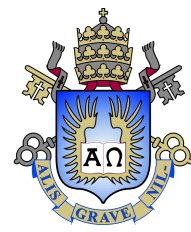

Alvaro Esteban Cox Lescano

\title{
Legal Capacity, Historical Development, and Firm Size: Evidence From Colonial Peru
}

Thesis presented to the Programa de Pós-graduação em Economia da PUC-Rio in partial fulfillment of the requirements for the degree of Mestre em Economia .

Advisor: Prof. Claudio Abramovay Ferraz do Amara 

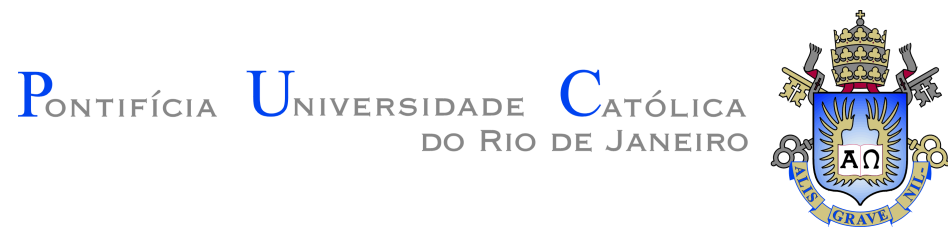

Alvaro Esteban Cox Lescano

\section{Legal Capacity, Historical Development, and Firm Size: Evidence From Colonial Peru}

Thesis presented to the Programa de Pós-graduação em Economia da PUC-Rio in partial fulfillment of the requirements for the degree of Mestre em Economia. Approved by the undersigned Examination Committee.

Prof. Claudio Abramovay Ferraz do Amara

Advisor

Departamento de Economia - PUC-Rio

Prof. Juliano Junqueira Assunção

Departamento de Economia - PUC-Rio

Prof. Leonardo Monteiro Monasterio Instituto de Pesquisa Econômica Aplicada - IPEA

Prof. Augusto Cesar Pinheiro da Silva

Vice Dean of Graduate Studies Centro Técnico Científico - PUC-Rio 
All rights reserved.

\section{Alvaro Esteban Cox Lescano}

B.A. in Economics by the Pontifical Catholic University of Peru (Lima, Peru), 2013

Bibliographic data

Cox Lescano, Alvaro Esteban

Legal Capacity, Historical Development, and Firm Size: Evidence From Colonial Peru / Alvaro Esteban Cox Lescano; advisor: Claudio Abramovay Ferraz do Amara. - Rio de janeiro: PUC-Rio, Departamento de Economia, 2018.

v., 65 f: il. color. ; $30 \mathrm{~cm}$

Dissertação (mestrado) - Pontifícia Universidade Católica do Rio de Janeiro, Departamento de Economia.

Inclui bibliografia

1. Economia - Teses. 2. Development - Teses. 3. Capacidade do estado;. 4. Capacidade jurídica;. 5. Tribunais;. 6. Tamanho das empresas;. 7. Persistência histórica;. I. Ferraz do Amara, Claudio Abramovay. II. Pontifícia Universidade Católica do Rio de Janeiro. Departamento de Economia. III. Título. 
To my dear grandparents, family and Jeanette for their support and encouragement. 


\section{Acknowledgments}

I would like to first thank my advisor Claudio Ferraz for the patience, his predisposition to hear my doubts and the good advices he gave me. Also, I would like to thank the economic department of the PUC-Rio for two wonderful years in an environment where knowledge, self-discipline and friendship are promoted. To my classmates for all those experiences that will always remain in my heart.

Then I wish to thank my parents, brother and cousins for being close despite the distance. Second, I want to thank my dear grandparents, Edwin and Carmen, which are one of my biggest motivations and support in life. Finally, I want to thank Jeanette Moreno, and her family, for her patience and love in these two years, I am very lucky to have you by my side.

To conclude, I thank CNPq and PUC-Rio for all the financial and administrative support. 


\section{Abstract}

Cox Lescano, Alvaro Esteban; Ferraz do Amara, Claudio Abramovay (Advisor). Legal Capacity, Historical Development, and Firm Size: Evidence From Colonial Peru. Rio de Janeiro, 2018. 65p. Dissertação de mestrado - Departamento de Economia, Pontifícia Universidade Católica do Rio de Janeiro.

In this paper, we focus on one channel through which state capacity explains differences in economic development: it's effect over firms. We rely on the literature of historical persistence to analyze the effect of historical legal capacity, a crucial dimension of state capacity, over the size and structure of firms through time. This relationship is studied for the Peruvian case. We use rich data from a historical census of the state administration carried in 1793 to analyze the persistent effect of legal capacity, and specifically from colonial courts, over historical and current firms' development indicators. We show evidence of a persistent and significant positive effect of historical legal capacity over several dimensions of firms' development (size and productivity) and structure (degree of market integration). Also, we collect information on race and literacy from a national population census held in 1876, and information on the initial distribution of firms from the registry of taxes in 1910s. Our evidence is robust to these important variables highlighted in the literature like human capital, initial distribution of firms, and racial heterogeneity. The presence of colonial courts appears to be the most important dimension of legal capacity. Third, we analyze the effect of colonial over the current presence of legal capacity as a potential channel of persistence. We observe that having legal capacity in the past affected the relative cost of subsequent investments in state capacity during the republic period. Finally, we have preliminary evidence on the different evolution of formal and informal norms. Municipalities with colonial legal capacity have loosened financial frictions and demand less informal credit. At the same time, there are no significant differences in the conditions to obtain a functioning license, a feature related to broad state capacity.

\section{Keywords}

State Capacity; Legal capacity; Courts; Firms' Size; Historical Persistence; 


\section{Resumo}

Cox Lescano, Alvaro Esteban; Ferraz do Amara, Claudio Abramovay. Capacidade Legal, Desenvolvimento histórico, e Tamanho de Firma: Evidência do Peru Colonial. Rio de Janeiro, 2018. 65p. Dissertação de Mestrado - Departamento de Economia, Pontifícia Universidade Católica do Rio de Janeiro.

Neste artigo, nos concentramos num canal através do qual a capacidade do Estado explica as diferenças no desenvolvimento econômico: o efeito sobre as firmas. Seguindo a literatura de persistência histórica nos analisamos o efeito da capacidade jurídica histórica, uma dimensão crucial da capacidade do Estado, sobre o tamanho e a estrutura das firmas ao longo do tempo. Esta relação é estudada para o caso peruano. Usamos dados dum censo histórico da administração do Estado realizado em 1793 para analisar o efeito persistente da capacidade legal e, especificamente, dos tribunais coloniais, sobre os indicadores de desenvolvimento das firmas históricas e atuais. Mostramos evidências dum efeito positivo persistente e significativo da capacidade jurídica histórica sobre várias dimensões do desenvolvimento (tamanho e produtividade) e estrutura das firmas (grau de integração do mercado). Além disso, coletamos informações sobre raça e alfabetização de um censo populacional nacional realizado em 1876 e informações sobre a distribuição inicial de empresas do registro de impostos em 1910. Nossas evidências são robustas a essas variáveis importantes destacadas na literatura, como capital humano, distribuição inicial de empresas e heterogeneidade racial. A presença dos tribunais coloniais parece ser a dimensão mais importante da capacidade jurídica. Em terceiro lugar, analisamos o efeito do colonial sobre a atual presença de capacidade legal como um potencial canal de persistência. Observamos que ter capacidade legal no passado afetou o custo relativo de investimentos subseqüentes na capacidade do Estado durante o período republicano. Finalmente, temos evidências preliminares sobre a evolução diferente das normas formais e informais. Municípios com capacidade legal colonial afrouxaram os atritos financeiros e exigiram menos crédito informal. Ao mesmo tempo, não há diferenças significativas nas condições para obter uma licença em funcionamento, uma característica relacionada à capacidade geral do Estado.

\section{Palavras-chave}

Capacidade do estado; Capacidade jurídica; Tribunais; Tamanho das empresas; Persistência histórica; 


\section{Table of contents}

1 Introduction $\quad 11$

2 The Peruvian Case $\quad 17$

2.1 The Foundation of Cities and Establishment of the Town Halls 17

2.2 The Colonial Administration of Justice 20

3 Data 23

$4 \quad$ Empirical Strategy $\quad 30$

5 Results 32

5.1 Historical legal capacity presence and Firms' development 32

$\begin{array}{lll}5.2 & \text { Alternative explanations } & 35\end{array}$

5.3 The persistence over time 44

$\begin{array}{lll}5.4 & \text { Legal capacity persistence } & 47\end{array}$

5.5 Alternative specifications $\quad 50$

5.6 Exploring mechanisms $\quad 55$

6 Conclusions $\quad 58$

$\begin{array}{ll}\text { Bibliography } & 60\end{array}$

$\begin{array}{ll}\text { A Published paper } & 65\end{array}$ 


\section{List of figures}

Figure 3.1 Colonial and Present System of Roads 25

Figure 3.2 Colonial and Present Legal capacity Distribution 27

Figure 3.3 Colonial Courts 28

$\begin{array}{lll}\text { Figure 3.4 Other Colonial Inst. } & 28\end{array}$

Figure 3.5 Colonial Legal capacity Institutions 28 


\section{List of tables}

Table 3.1 Data set description 24

Table 3.2 Legal capacity Index 26

Table 3.3 Balance of Geographical Characteristics 29

Table 5.1 Historical Persistence - Baseline Results 34

Table 5.2 Historical Persistence $1 \quad 36$

Table 5.3 Historical Persistence 2 37

Table 5.4 Historical Persistence $3 \quad 38$

Table 5.5 Historical Persistence 1 - Importance of Courts 41

Table 5.6 Historical Persistence 2 - Importance of Courts 42

Table 5.7 Historical Persistence 3 - Importance of Courts 43

Table 5.8 Historical Persistence - Sectoral Analysis 44

Table 5.9 Historical Persistence Over Time (1954) 45

Table 5.10 Historical Persistence Over Time (1954) - Importance of Courts

Table 5.11 Legal capacity persistence 48

Table 5.12 Legal capacity transition matrix 49

Table 5.13 Robustness - IV Model 1

Table 5.14 Robustness - IV Model 2

Table 5.15 Robustness - Network Model 54

Table 5.16 Exploring Other Mechanisms 57 


\section{Introduction}

The differences in economic development observed across countries are mirrored by the differences observed in the productivity level. As we addressed the productivity level of a country, we need to understand its productive capacity which is largely related to the creation, development, and dynamics of firms. Firms, as economic agents of a society, are affected by the quality of institutions and the actions of the State. There is an extensive discussion about the influence of politics on the productive sector of the economy addressed and formalized by (1). The positive correlation between state capacity and economic development allows us to think that having a capable state is an important feature of developed economies.

The institutional literature emphasized the importance of state capacity formation to explain the observed differences in economic development. The enforcement of State presence is far from being homogeneous and is closely related to the historical development of the State and strengthening of civil society $((26),(44),(23),(35)$ and (8)). Some explanations highlight the risk of engaging in external wars, the pressures to homogenize by compulsory education the preferences of citizens, the stability environment observed by the political groups governing and the transplantation of legal systems; as potential factors to understand state capacity formation $((29),(6),(42)$ and (26)). At the same time, we observe the development of heterogeneous forms of government within countries too. (10), (39) and (3); report the heterogeneous historical development of the State in India, Brazil and Colombia; and the implications over current State capacity and economic development ${ }^{1}$. As an overall, state capacity is quite heterogeneous between and within countries and the historical events are quite important to explain the observed differences.

One dimension of State capacity is related to legal state capacity. Institutional economists explain that States write and enforce formal rules in order to create a homogeneous framework to base economic and social interactions between individuals. This framework reduces the risk of arbitrarily

${ }^{1}$ Also, (20) and (12) highlights other dimensions, related to trust, corruption and local governance, affected by the historical differences in the government established in Vietnam and in a set of countries in Eastern Europe that were part of the former Habsburg empire. 
impart justice in environments where economic inequality can influence the result of a trial. Then, governments create detailed legal frameworks and procedures to determine the nature of property rights and enforcement of contracts in a wide scope of cases. The importance of property rights and enforcement of contracts to explain the heterogeneity in development have been extensively studied in the literature (for example, (24), (21), (2) and (33)). For us, these two dimensions give economic agents a stable environment to make economic decisions, and so, are central to the development of firms.

As the importance of the development of State capacity has proved to explain well part of the differences observed in economic development, great efforts are being made to better understand the mechanisms that drive this relationship. Moreover, there is still debate about the factors behind the persistence of past to current State capacity. In this direction, our paper addresses two questions on this topic. First, we explore whether historical State capacity affects economic development via its effect on the development of firms. We circumscribe our definition of State capacity to its legal capacity dimension, the presence of colonial courts and other legal capacity institutions. The importance of the persistence of colonial legal capacity for firms comprises the enforcement of formal rules which might affect property rights' definition $((21)$ and $(22))$, the decisions of formalization ((50)), to write contracts between firms and providers affecting the degree of vertical integration $((7)$ and (37)), or access to credit in the financial sector ((13) and (14)). These are economic interactions that affect firms' performance. Second, we analyze the persistence of the legal capacity dimension over time in a country labeled as a weak State. This second query expands existing theory on State capacity formation as it gives more insights on the legal dimension of the State.

In order to answer these two questions, we collected data from a colonial census held in 1793 to analyze if the colonial physical presence of legal capacity, and specifically, of colonial courts, has a persistent and significant effect on market development by looking to firms' development. In theory, those places with historical legal capacity had better access to register property rights and enforce contracts than other near municipalities, similar in other dimensions to the former, but without legal capacity. Why could the physical presence of colonial legal capacity be important to generate differences in market development? First, it would be cheaper to invest in State capacity in those places where it already exists than to engage on the broad costs of creating a State in other places. This fact would generate a persistent difference in the broad access costs and the experience of courts in their interaction 
with economic agents. Second, formal and informal rules may evolve and develop differently in places with and without the physical presence of legal capacity, especially for a weak State. These and other features may influence the development of markets and firms across the territory.

Our empirical strategy is justified by historical accounts that describe the formation of the colonial State which was closely related to the creation of cities. Spaniards created cities in order to advance the exploration of the territory, established secure places to rest while traveling between important cities and marked the extension of the territory conquered. The creation of cities implied the planning of the city and the establishment of the Town Hall council or "Cabildo". These institutions served to elect Majors whose main responsibility was to impart justice. As argued by (25) and (38), the exact location of the new colonial cities, even when there existed a general blueprint on colonization structured by the monarchy, was driven in several cases by idiosyncratic factors that can be considered exogenous for current outcomes. In fact, all municipalities around the selected ones seem to be good counterfactuals if we consider how Spaniards decided where to settle a "city". We use this fact on the colonization process in Peru to analyze the long-term effects of colonial legal capacity.

Our baseline results showed that firms in municipalities with colonial legal capacity experienced gains in efficiency as they prefer to interchange within markets rather than adopting a vertical structure. Also, those places have more formal firms per capita, firms have a larger size (measured by sales and workers) and higher labor productivity. The colonial presence of courts appears to be an important dimension of the colonial legal capacity. These results shed light on the importance of the legal capacity formation of the State in promoting the development of markets and firms. Also, our results point in the same direction of (35) who highlights the importance of contracting institutions in addition to broader property rights institutions; and complements the findings of (2) showing that, in the case of firms, property rights and contracting institutions are both quite relevant for development.

Our results are tested against alternative explanations regarding (i) colonial fiscal capacity, (ii) historical human capital, (iii) racial heterogeneity, and (iv) initial conditions for market development. First, we collected data on colonial administrative bureaucrats and on the distance from municipalities to the colonial roads, the main public good provided from the State in that time, to test for the fiscal capacity effect. Second, we collected data from a national population census held in 1876 with information on racial distribution 
and literacy rates of the population. Finally, we use data on the number of industrial firms operating in the territory in the 1910s as an additional control to assess reversal causation concerns. Our results are quite robust and stable with the addition of this important variables. Moreover, our results are robust to the exclusion of important cities like Lima, the capital of Peru.

Furthermore, we evaluate how colonial institution affected the development of firms over time. Then, we collected firm-level data for the manufacturing sector in 1954 coming from the Ministry of Production at that time. Using the same strategy and historical controls than our baseline model, we obtain that the persistence of colonial institutions is observed. The presence of colonial legal capacity institutions positively and significantly affected the number of formal firms per capita and the mean size of the firms. The results are robust to the addition of the historical control mentioned and the exclusion of important observations.

The second question analyzes the formation of legal capacity in Peru, we show that colonial legal capacity is persistent over time and explain the current distribution of legal institutions. We argue that historical State formation change the relative cost of subsequent investments in State capacity formation. We use a wide measure of the presence of the colonial and current legal capacity to study historical persistence in this dimension of State capacity. The features of legal capacity presence considered are related to the presence of courts, notary offices, registry offices, and police stations (and its parallels in the colonial period). Furthermore, we estimate a matrix of correlation between both indices, historical and current legal capacity, to analyze persistent within dimensions and obtain that the dimensions within the index are also persistent. This is, if a municipality did not have courts in the colonial period, then it would be less likely to find courts in the present. Our results shed light on a potential mechanism behind the relationship between colonial legal capacity and firms' development over time.

As a robustness check, we test different models to test the effect over firm's development. We estimate two IV models. First, we use the colonial State presence of legal capacity as the instrument of current legal capacity. We use the persistence observed in legal State capacity to justify the first stage of this model. Results go in the same direction that points our baseline specifications. Second, as explained below, distance to colonial roads may be an important determinant of the foundation of cities. Then, we use distance to colonial roads as instrument for our index of colonial legal capacity. Again, the results are similar to the ones obtained in the baseline model. Finally, we follow 
(3) and estimate our model in a network framework to evaluate how neighbors of municipalities with historical legal capacity are affected. Our results showed that being neighbor of a municipality with colonial legal capacity has a positive but tiny contribution to the development of firms.

In addition, we present preliminary evidence on the mechanisms behind the effect of legal capacity over firms. We use two firms' surveys to evaluate how State related constraints vary with colonial legal capacity. We obtain evidence that firms in places with legal institutions in the past have loosened financial frictions, more access to credit markets, and less informal credit demand. This highlight one feature of the different evolution of formal and informal norms in the relationship with the State. Furthermore, we performed a placebo exercise using information on the quality of the process to obtain a license for operation and expansion of infrastructure, two features related to broad State capacity. Our findings show that there is no significant difference between treated and non-treated municipalities. Results give us preliminary evidence on the evolution of norms as a function of historical legal State presence. Further work is needed to trace down these potential mechanisms more rigorously.

There are some contributions on the link between State capacity and firm's development. (4) highlights the central role of US State in boosting the wave of innovations that took place in the 19th century via a wide and well-connected network of post offices that channeled ideas and inventions all around the country. Related to the legal capacity of the State, (35) showed how a higher quality of the legal system reduces the idiosyncratic risks faced by entrepreneurs, and so, affects positively several measures of firm size for the Mexican case. For the Brazilian case, (43) used variation in the congestion of civil courts across Brazilian municipalities to estimate the effect of enforcement on access to credit, investments, and size. Related to vertical integration, (37) argue that when transaction costs are important and markets are far from operating efficiently, vertical structures in firms may arise. Then, the presence of legal capacity may be a first-order improvement in the contracting environment that may incentive specialization in fewer stages of production.

Our paper contributes to the literature by analyzing an important relationship in the State Capacity literature, how historical legal capacity affected the development of markets in different dimensions. First, the availability of rich data coming from a historical census of the colonial State administration in Peru held in 1793 helped us to measure legal capacity. Accordingly, we can analyze different dimension of the legal capacity index, its persistence over time 
and the effect over firms' development. Also, we use valuable data on firms' indicators coming from the Tax Collector and the National Economic Census at different points in time (the 1910s, 1954 and 2007-2015). These sources allowed us to focus on one potential mechanism through which historical State capacity explain economic development: the effect of historical legal capacity over firms. Furthermore, we expand and give more insights on the evolution and strengthening of the State in one specific dimension, the legal capacity.

Our research relates to the literature on the persistence of historical events on current economic development. The work of (19), regarding the longterm effects of the Mita institution in Peru, is one of the first contributions in this literature. Other contributions in this line are the research of (39) and (10) on the institutional persistence of colonial features in present economic development. Also, (46), (40) and (52); are important contributions centered on certain historical events have long-term persistence in the human capital dimension.

The rest of the paper is structured as follows. Section 2 presents a historical overview of Colonial Peru. Section 3 presents the database that will be used. Section 4 presents the empirical strategy used to address the questions posed. Section 5 presents our main results on historical persistence, alternative explanations, robustness and a preliminary exploration of the mechanisms. The last section concludes. 


\section{2}

\section{The Peruvian Case}

Peru, a former colony of the Spanish Empire, was the administrative capital of the large Viceroyalty in South America. The origins of the colony date back to the conquest of the Inca Empire by the Spanish expedition commanded by Francisco Pizarro between 1532 and 1535. The colonial project led by the Metropolis in Spain had a specific goal, the new domains had to generate wealth, gold and silver, and ship it to the metropolis. Nevertheless, the pattern of colonization and creation of a State to govern the new land became more complex and troubled. The colonizers had to secure the new domains by expanding its presence through the creation of new cities or the establishment in former Inca cities. Then, the administration in judicial matters and security of the cities was an additional priority besides the mineral extraction (45).

We address historical accounts describing the administration of justice in the colonial period and the process of colonization based on the foundation of cities. The creation of these settlements determined the distribution of the Colonial State across the territory. Furthermore, (25) mentions that these cities and the "reducciones", indigenous towns created by Viceroy Toledo, were the ancestors of the urban agglomerations that exist today. After the independence war, the remaining Spaniards elites in control of the state were deported and the young republic inherited the colonial state distribution to establish the new nation objectives ((34), (32), and (18)).

We begin to describe the process of colonization based on the foundation of colonial cities. Then, we analyze the judicial dimension of the colonial administration and give some examples of the type of cases that were seen by colonial courts.

\section{1}

\section{The Foundation of Cities and Establishment of the Town Halls}

The extensive work of (38) gives a deep understanding of how cities and Town Halls were founded in Peru. Moore described that the procedures established by the Metropolis gave colonizers general directions about the rules to be followed in the location and planning of a city. The general procedures 
came from "royal edicts and decrees, later compiled in the famous Recopilacion of 1680, [...], and customs handed down from the medieval Castilian cities. All these were influential [...] in the formation of the Hispanic American Municipality (Moore, 1954, pp. 48)". This general blueprint advised that the foundation of cities should follow general instructions based on geographic features of the location.

According to (25), the creation of cities was driven by three premises. First, they built cities to advance the exploration of the territory, "towns were founded in order to protect and facilitate the construction of highways and lines of communication with the interior or hinterland (Moore, 1954, pp. 52)". Second, to establish secure places to rest while traveling between important cities like Lima, Cuzco or Potosí. The third "consisted in marking with the cities the possession of the conquered territory, which was reflected by the foundation of a settlement and an administrative and judicial body [...] (Espinoza, 1997. pp 113)." Following the general blueprint, Spaniards chose strategic locations near rivers and/or small streams. Also, the cities were located in relatively extensive plains with an agricultural potential to secure the subsistence of the settlement. Some of them were built in ancient indigenous farming locations.

Nevertheless, the foundation of the city became a more complex issue in practice. We can mention some examples of how the Spaniards created some cities to illustrate the irregular settlement pattern and the idiosyncratic factors that influenced the foundation of several cities. First, Espinoza describes that Trujillo, a major city to the north, was an example of a city founded in special circumstances. Pedro de Alvarado, a military commander, try to create its own region with him as the Governor, stealing the space appointed to Francisco Pizarro. The last prepared the defense of the territory and sent Diego de Almagro "El Viejo" to repel the intruder. Almagro departed from Pachacamac, a small city to the north of Lima, and traveled to the north passing by the Chimo valley, where he saw a great space to establish a settlement. After he accomplished his mission, he meditated to create a city near the Chimo valley. Some years after, the new settlement was created with the name of Trujillo.

A second example is the foundation of Huanuco, a city in the highlands of Peru. Pizarro asked the captain Gomez de Alvarado to defeat the Inca Illac Topa resistance. He established a settlement in the plain of Huanucopampa, a suitable place to live. Nevertheless, the continuous confrontations with the Inca and the winter in the highlands expelled the settlement to the valley of Pilco near the Huallaga river. This is the actual location of the city. A third atypical case was the foundation of Huamanga. As (25) mentions, "Huamanga 
was established in order to provide security from indigenous attacks to those Spaniards traveling from Lima to Cuzco". Then, Spaniards chose its location around the colonial roads used by travelers. Finally, we have the foundation of Jaen. This city was an important economic space thanks to the mineral washes that existed there and the important number of indigenous people forced to work. Those reasons are no longer relevant for the current development of firms.

After the location was selected, Moore mentioned that the general framework "prescribed the chief governmental powers to be wielded by the founder: the allotment of property to the neighbors of the new settlement; the appointment of members of the first Cabildo; and the exercise of appellate jurisdiction in civil and criminal matters during his lifetime (Moore, 1954, pp. 48)". In the same direction, (30) writes that once the Spaniards chose and established a settlement, they enrolled the future residents and traced the plans of the city, "then they proceeded to denote the blocks, streets, the places to build houses, the temple, the royal houses, the Town Hall or council, the customs house, etc. [...] As for the Town Halls, the "Indian Laws" established moralizing recommendations, such as that of the town councils holding elections for mayors and other officials [...]". Then, the foundation of a new city implied the creation of Town Halls and the election of Ordinary Majors, the main characters in the exercise of justice ${ }^{1}$.

Given the pattern of settlement described by the historical accounts, we can infer that the specific limits of the districts and provinces, and the specific location of the cities; were chosen following a general blueprint that was heavily influenced by idiosyncratic factors given a superficial knowledge of territory and the complexities of the process of conquest in a place away from the metropolis. We rely on historical accounts to argue that by the time of the colonial period, the specific location of the places elected to set up the colonial legal institutions should be driven by observable geographic characteristics and idiosyncratic factors that are not longer relevant to understand firms' development in the present. A similar approach is used by (3).

\footnotetext{
${ }^{1}$ As an example of the foundation of the cities and Town Halls, we can mention the transcription made by (47) of the original first text written in the Cabildo of the city of Cuzco. This historical record details the establishment of the terms and district limits of the city, the first mayor and aldermen, the assignment of the Governor of the city, the distribution of land for the dwellings of the first neighbors, and other details. The establishment of a city was a broad project that comprises the establishment of the Town Hall. This assembly had the obligation to represent the first administration of the city, the mentioned major or ordinary Mayors and its council or aldermen. In Cuzco, it was Francisco de Toledo who promoted the foundation of the city and appointed the first Cabildo of the city. The first Mayor of Justice and, at the same time, Corregidor of the city was the Licenciado Polo de Ondegardo.
} 
We continue the next section with a brief description of the judicial dimension of the colonial administration and, specifically, of the Town Halls established that decided over judicial matters.

\section{2}

\section{The Colonial Administration of Justice}

During the legacy of the Austrian Kings, the Spanish monarchy became absolutist. It centered all the power in the King's hands and, at the same time, enforced a bureaucratic body to administrate their domains. The pillars of this bureaucracy were the Councils, whose role was not limited to advice the king but to structure the bureaucratic organization and functions in administrative, legislative and judicial matters ((41), pp. 119). The bureaucratic hierarchy established in the colonial domains was organized into three levels: (i) A central body of government composed by the Viceroy and the "Real Audiencia", (ii) a region-province body composed by the Governors and "Corregidores", and (iii) a local bureaucratic body composed by the Town Halls ("Cabildos") chaired by the Ordinary Mayors.

The Viceroy was the highest authority in the colony. He was the chief of the three main functions of the colonial state, administration, economy, and justice (he was the president of the "Audiencias"). The appointment of the Viceroy came from the Metropolis and, in colonial grounds, he personified the authority of the king. In parallel, the "Real Audiencia" was the most important judicial institution in the colony. This council functions as the last instance in judicial disputes in civil, administrative and criminal matters. Following (51), to the "Real Audiencia" came, in the second instance, the causes failed by ordinary Mayors, Governors, and "Corregidores"; that were appealed. Also, it could appoint supervisors to evaluate the activity of the subordinates in the judicial bureaucracy ${ }^{2}$.

In a second level of the colonial bureaucracy, the Governors or "Corregidores" decided over political and judicial matters, and were also commanders in their specific locations. In Peru, they were appointed by the king and his position lasted 3 years. They were in charge of the Corregimientos, subdivisions of the Audiencias, that in Peru reach the number of 52 by 1780 . The Corregidor lived in the most important city of each Corregimiento but had to rule the whole extension. The "Corregidores" chaired the town meetings when they were present in a town. Following historical accounts, "they were appointed to administrate Spaniard cities, where civil life developed [...]. They were in

\footnotetext{
${ }^{2}$ We can mention the case of Antequera, Oidor, and President of the Audiencia of Charcas, who was judged and convicted by the Real Audiencia.
} 
charge of the collection of taxes in its jurisdiction and the administration of justice in the cities ((51), pp. 58-59)".

Finally, our research focuses on the local level of government. The Town Hall council was the institution that was directly responsible for election of Ordinary Majors. Following (51), "this was the most important institution of government and justice that the colonial regime implanted. Even when they did not act as courts, the judges emanated from their bosom, in civil and criminal matters, that guaranteed the right of the community". Ordinary Majors, a position appointed by-elections in the Town Hall, exerted their authority in judicial matters in cities with Town Hall. They had knowledge of the civil and criminal cases, but their decisions could be appealed to the respective Audiencia. Around the Mayor, in the Town Hall, other officials functioned as bureaucrats, "these were the general prosecutor of the Town Hall that had to understand the processing and prosecution of lawsuits emanating from the settlement; the legal advisors, who presented their opinion to the mayors; and the senior "Escribano" of the settlement, who had to write, organize and store the public documents that were part of the settlement ((51), pp. 60)".

In addition, there were some Indian Mayors "who protected the Indigenous population in the preservation of their native judicial norms, as long as they were not in opposition to the Spanish legal system ((51), pp. 61)". (31) wrote extensively about the process of how the indigenous population obtained more rights in the colonial world. The existence of these natives authorities gave indigenous people some representation in the colonial world.

It deserves to mention that, after the Tupac Amaru II (1780-83) revolution, the Bourbon Reforms and the creation of the new institution of Intendencias; the judicial regime was not substantially altered. The elimination of the Governors, Corregimientos, and the Corregidores, came jointly with the designation of Intendentes and Subdelegados. These new authorities were in charge of the administration of justice in its respective Intendencias, but within the same judicial framework used previously.

In order to illustrate the usual cases examined in the courts, we list some files obtained from the historical registries of some Cabildos.

1. 02 March 1571. Trujillo. The case followed by Don Francisco Flores, neighbor of Trujillo in the criminal complaint with Mr. Francisco Menacho, a neighbor of the Villa de la Parrilla, about being ordered to [...] convict for the undue collection of 250 pesos in current silver, according to a cedula. Concluded: 14 July 1571. 
2. 29 April 1605. Trujillo. The case followed by Mr. Cristobal Montalvo against Luis Gonzalez Velasquez on request for 600 peso silver debt. Concluded: 19 April 1607.

3. 09 January 1647. Trujillo. The case followed by Don Antonio Josef de Silva Manrrique, Ordinary Mayor of the city of Trujillo, against Domingo Negro and Francisco and the "mulata" Catalina, Slaves of the Captain Don Juan Rodriguez de Olmedo Mayor of Aguas, on a theft of the amount of 400 pesos owned by Don Antonio Justiniano. Concluded: 09 May 1947.

4. 1617. Cuzco. The case followed by Antonio Ramos, owner of recua, against Lorenzo de Castro, for the collection of 1050 pesos.

5. 1625. Cuzco. The case followed by the defender of the property of deceased, for the goods of Juan Tarma Amaro, Indian stranger of the parish of Santa Ana, against Magdalena Tocto, by appropriation of his property.

6. 1643. Cuzco. The case followed by Pedro Carrasco, merchant, against Bartolome Martin Mangas, cajonero, for the collection of 1203 pesos.

7. 1648. Cuzco. The case followed by the lawyer Don Andres de Morales, against Mr. Rafael de Subieta, principal debtor, and Mr. Bartolome Perez, as his guarantor, for the collection of 12,000 pesos. 


\section{Data}

For our analysis, we compile a large database that accomplishes to map the sub-national level of Peru in five main dimensions, firms' development indicators over time, colonial legal capacity, current legal capacity, firms' perceptions on the relationship with the state, and other controls relevant in the Peruvian case. The complete set of variables used is presented in table 3.1. We obtained data on firms from the National tax collector and from a national economic census held in 2007. The variables used are the number of formal firms per capita, two measures for the size of the firm (mean value of sales and workers), the mean sales per worker (a proxy of the efficiency of the firm), ownership structure measured as an index from 1 to 4 (ordered in increasing order from individual forms of ownership to anonymous societies), and vertical integration which is measured following (35) as the ratio between value-added and sales. A firm is more vertically integrated when the index approaches one.

Furthermore, we collected two additional firm level databases in 1954 and 1910s. The first data is used to analyze the evolution of the persistent effect of colonial legal capacity over time. We have data on the number of industrial firms and the number of workers in each one. Then, we can analyze the effect of colonial legal capacity on the number of formal firms per capita and the mean size of them, measured as the number of workers. We use the second source to control for potential reverse causation, where the initial level of firms affected the subsequent distribution of courts. We obtained two additional variables from this source, the number of formal firms and the mean size measured as sales in the 1910s.

To analyze the persistence of colonial legal capacity on current outcomes we use colonial historical data. By 1793, the anatomy professor at the Real University of San Marcos, Joseph Hipólito Unanue, was commanded to elaborate a general state of the political administration in the Vice-royalty of Peru. Unanue structured his report into three parts concerning each of the powers ruling the colony: political, religious and military powers. We benefit greatly from this document that identifies the number and function of the bureaucrats, 
Table 3.1: Data set description

\begin{tabular}{llc}
\hline \multicolumn{1}{c}{ Variable } & \multicolumn{1}{c}{ Sources } & Years \\
\hline Firms related variables & National Tax Collector & $2007-2015$ \\
Number of Formal Firms & National Tax Collector, & $2007-2015$ \\
$\begin{array}{l}\text { Mean Size of Firms - workers } \\
\text { Mean Labor Productivity }\end{array}$ & National Economic Census & 2007 \\
$\begin{array}{l}\text { Ownership structure } \\
\text { Vertical Integration }\end{array}$ & National Economic Census & 2007 \\
$\begin{array}{l}\text { Number of Manufacturing Firms } \\
\text { Employment by Firm in 1954 }\end{array}$ & Registry of Manufacturing Firms & 1954 \\
Number of Firms & Registry of Taxable Firms & $1910 \mathrm{~s}$ \\
\hline
\end{tabular}

\section{Colonial state presence}

Number of Judges

Number of Military and Police Officials

Number of Notaries (Escribanos)

Joseph Hipólito Unanue's

Number of Administratives National Census of Col. State

Number of Priests

Population in 1876

Racial distribution of population -1876

Literacy distribution of population-1876

Distance to Colonial Roads

National Population Census

Current state presence

Number of Notaries

Laviana (1986)

Number of Civil Judges

Number of Crime Judges

Number of received judicial processes

Number of sentenced judicial processes

Number of police stations and officers

Number of workers registered in municipalities

National Directory of Notaries

National map of dependencies of judges

National census of police stations

Distance to Current Roads

RENAMU

Firms' Perceptions

On access to formal credit

Ministry of Transportation and Communications

2012

On access to broad government services

National Survey of Firms

2011-2015

\section{Other Controls}

Latitude

Longitude

Mean Depth and Slope of the territory

Surface

SRTM 90m Digital Elevation

Mean rainfalls

Database from Ministry of Environment

Elevation

Cultivable area

River density

Population 
salaries paid and the specific location of each state institution. Specifically, we have data on colonial institutions related to the legal capacity of the state. We use the colonial census to create a hierarchical index of past legal capacity that will be explained below.

A second historical input is obtained from Laviana (1986) who recorded the specific location of colonial roads as is observed in figure 3.1. There is a high density of colonial roads, partially inherited from the Inca Empire, as Peru was for several years the capital of the colony. The colonial roads were the most important public good provided by the colonial administration. They were used by commercial routes within the Peruvian territory or beyond for the case of commerce with other parts of the Viceroyalty (Glave, 1989). The "arrieros" transported goods, using the newly mixture of animal they called "mule", through the network of roads. This map is geo-referenced and so, we are capable to calculate the distance of each municipality centroid to the historical royal road. Finally, we collected data from the National Population Census of 1876 to evaluate the different alternative hypothesis that may be driving the results observed without historical controls.

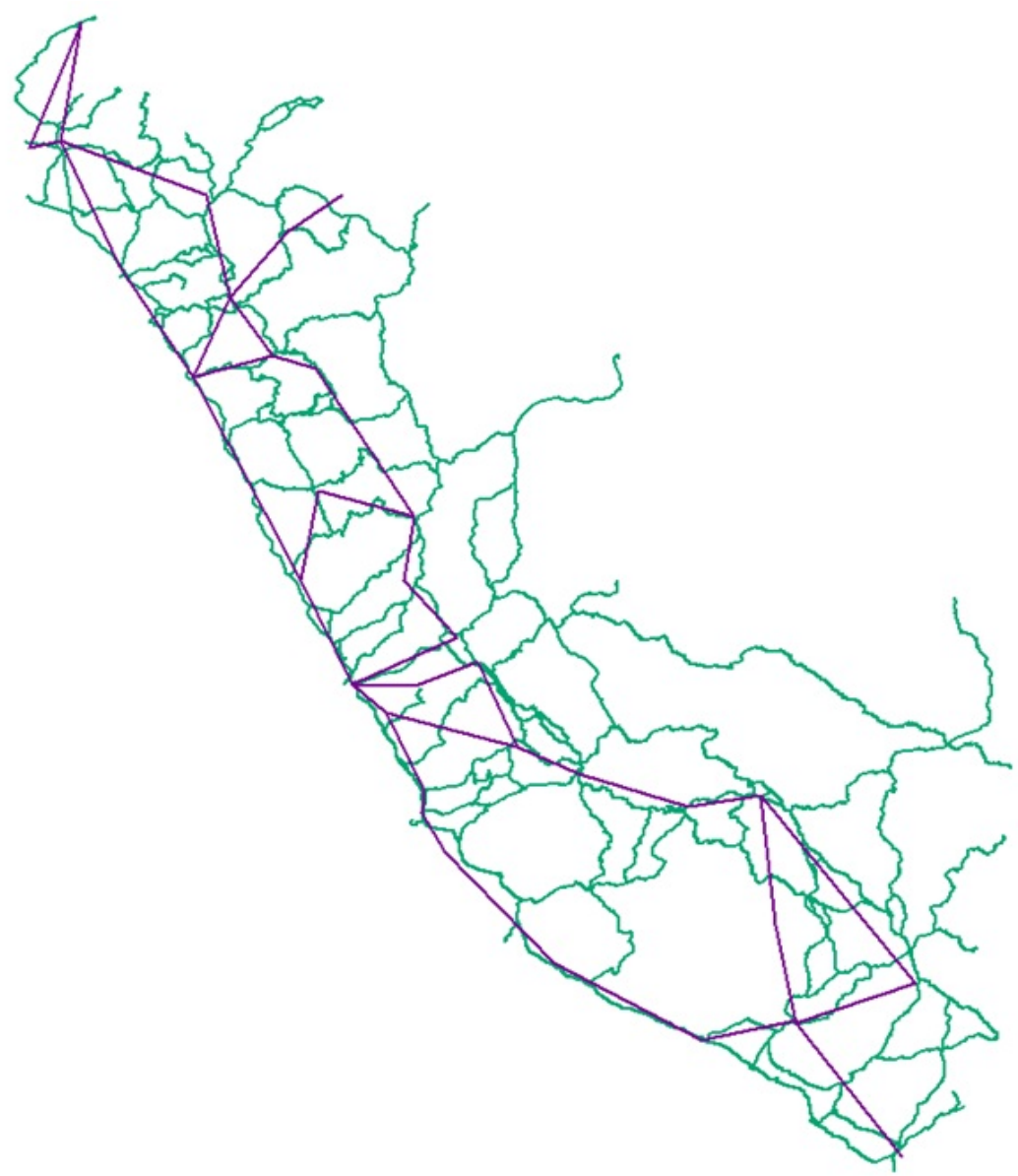

Figure 3.1: Colonial and Present System of Roads 
Table 3.2: Legal capacity Index

\begin{tabular}{rr|rr}
\hline \multicolumn{2}{c|}{$\begin{array}{c}\text { Colonial Legal capacity Index } \\
\text { Malue }\end{array}$} & \multicolumn{2}{|c}{ Current Legal capacity Index } \\
Value & \multicolumn{1}{c}{ Meaning } \\
\hline 0 & $\begin{array}{r}\text { Nothing } \\
\text { Post Service }\end{array}$ & 0 & $\begin{array}{r}\text { Nothing } \\
\text { Police Stations }\end{array}$ \\
2 & 1 1, Lawyers, Notary, Military and Police Officials & 2 & 1 , Notaries and/or Registry Offices \\
3 & 2, Courts & 3 & 2, and Civil Courts \\
4 & 3, Mayor courts and Real Audiencia & 4 & 3 and Superior Courts \\
& & 5 & 4 and Supreme Courts \\
\hline
\end{tabular}

The third set of historical controls are obtained from a population census collected in 1876 . This national census has information on race and the ability to read, write or both; at the individual level. The data is used to create indicators as the share of illiterates, the share of whites (the ruling race) and the total number of people. With this information, we can evaluate if our results on courts are driven by other social characteristics like the human capital, the racial distribution or the total number of individuals in the municipality. Then, we would be able to evaluate the main hypothesis on the causes of growth in a homogeneous environment.

The third dimension of the data is related to the current measures of legal capacity. They are obtained from different state institutions responsible for security within the country, registration of firms, registration of property and contracts, and civil courts. With the State information, we built a hierarchical index for the current and colonial period based on the presence of the State institutions. This approach is similar in spirit to (28) work. The detailed definition of the index is shown in table 3.2. Each number that the indices showed immediately include all institutions ranked below. For example, for the colonial legal capacity index, if a municipality has a value of 3 , then this municipality has courts; lawyers, "Escribanos" (today notaries) and "Gendarmerie" (today police stations and officials); and post service (colonial state offered post services).

Both variables, the colonial and current presence of legal capacity, are the core variables to evaluate legal capacity persistence over time. Figure 3.2 presents the histogram of our colonial and current indices over a total of 1832 municipalities considered. We have nearly $15 \%$ of municipalities that have the presence of colonial legal institutions, what we would consider as treated municipalities. Furthermore, we perform some comparative analysis between specific dimensions of the colonial index. In order to observe the spatial location of courts and other legal capacity institutions (Escribanos, Gendarmeries and Post Offices), the map in figure 3.5 shows the distribution of this two types of legal capacity institutions over the territory. The distribution is widespread 
across the territory, giving some generality to our results.
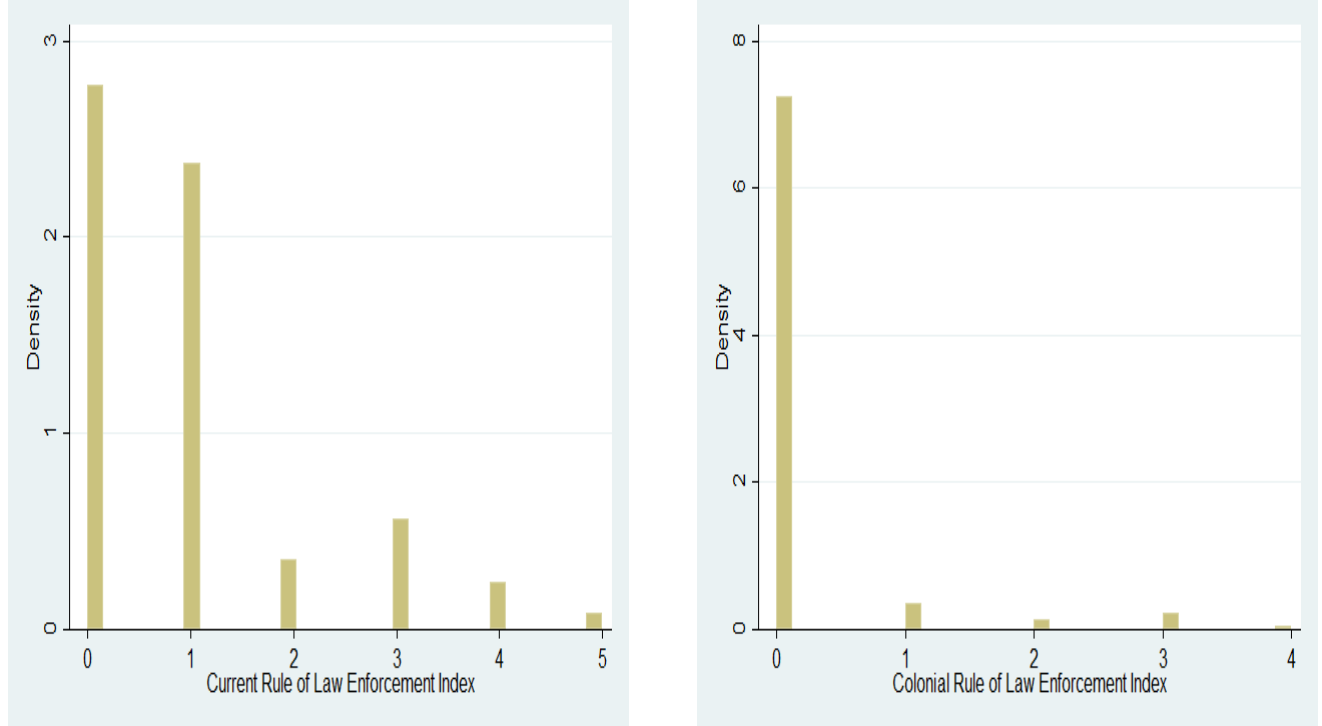

Figure 3.2: Colonial and Present Legal capacity Distribution

Fourth, we make a preliminary assessment of the differential evolution of formal and informal norms comparing places with colonial legal capacity and without it. We use two national surveys of firms with information regarding the perceptions of firms on the relationship with the State. We use two question focus on the legal capacity of the state: (i) how difficult is to obtain a formal credit in your municipality (answer rank from 1 to 4 , where 4 is quite difficult), (ii) Have you sought financing in the informal market? (yes or no answer). Moreover, we use an additional government service related to the fiscal capacity of the state as a placebo exercise: (iii) How difficult is it to obtain an operating license for your business? (answer rank from 1 to 4 , where 4 is quite difficult). Here we want to measure one specific side of cultural norms regarding the interaction with the state.

The fifth component of our data is related to the geographical characteristics of the municipalities. We add the geographical variables that allow us to check the balance on these characteristics that were central to the location of the new colonial cities. We collected information on the georeferenced location and elevation ${ }^{1}$ of municipalities. This dimension allows us to compute the distance to current and colonial roads. Also, we use the information to compute a matrix of geodesic distance and elevations between municipalities ${ }^{2}$ to correct for spatial correlation in the errors, and to perform a robustness exercise eval-

\footnotetext{
${ }^{1}$ This dimension is of great importance for the Peruvian case. As its territory is crossed by the Andean mountains, the difficulties of communication between municipalities are greatly explained by the variation in elevations.

${ }^{2}$ Also referred "as the birds fly" distance.
} 


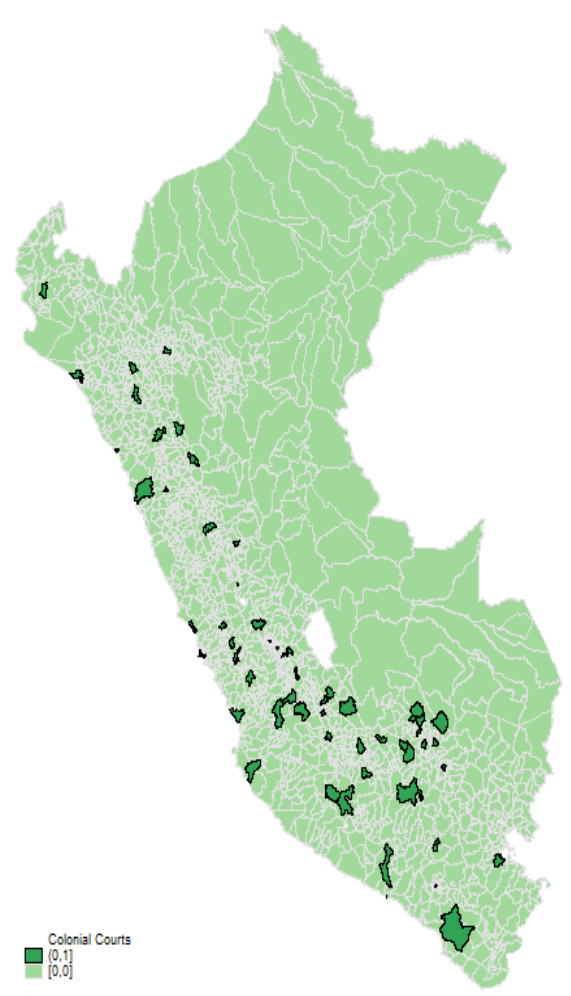

Figure 3.3: Colonial Courts

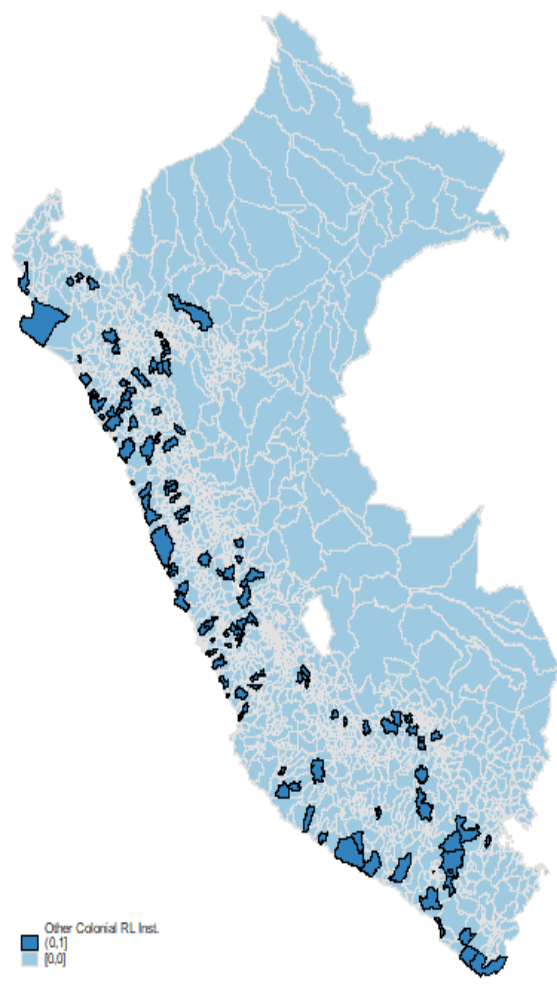

Figure 3.4: Other Colonial Inst.

Figure 3.5: Colonial Legal capacity Institutions

uating the spillover effects of a neighbor with colonial legal capacity as in (3).

In addition, we complement the set of geographical covariates with the other dimensions considered in the foundation of cities. First, we add geographical variables like surface area, cultivable area, river density, mean depth and slope of the surface and rainfalls ${ }^{3}$. All information is collected from the municipality level map from MINAM. This set of covariates are used in our baseline model for estimation too.

Finally, we analyze how our main covariates used in the baseline estimations are balanced using the colonial legal capacity index as the running variable. This information is presented in table 3.3. Geographical variables like elevation, surface, cultivated surface, depth and slope of the territory; are fairly balanced between groups which means that we will be able to analyze the relationship of interests in different geographical situations.

The balance observed suggests that there were several other places with similar geographical conditions to the ones chosen by the Spaniards to establish the new settlements. Then, it may be reasonable to think that the location

${ }^{3}$ The data is collected from SRTM 90m Digital Elevation Database v4.1 
Table 3.3: Balance of Geographical Characteristics

\begin{tabular}{|c|c|c|c|c|c|c|c|c|c|}
\hline $\begin{array}{l}\text { Colonial Legal Capacity } \\
\text { Variables }\end{array}$ & $\begin{array}{l}Y=0 \\
\text { Mean }\end{array}$ & $\begin{array}{c}Y=1 \\
\text { Mean }\end{array}$ & $\begin{array}{c}Y=2 \\
\text { Mean }\end{array}$ & $\begin{array}{l}\mathrm{Y}=3 \\
\text { Mean }\end{array}$ & $\begin{array}{c}Y=4 \\
\text { Mean }\end{array}$ & $\begin{array}{l}\text { Mean } \\
\text { T-Test }\end{array}$ & $\begin{array}{l}\text { Ot.St.Cap. } \\
\text { Mean }\end{array}$ & $\begin{array}{l}\text { Courts } \\
\text { Mean }\end{array}$ & $\begin{array}{l}\text { Mean } \\
\text { T-Test }\end{array}$ \\
\hline Current LC Index & 0,83 & 1,54 & 2,36 & 3,06 & 4,13 & 0,000 & 1,77 & 3,21 & 0,000 \\
\hline Elevation & 2.256 & 1.852 & 1.817 & 2.558 & 1.924 & 0,829 & 1.841 & 2.470 & 0.340 \\
\hline Surface & 71,7 & 59,2 & 53,9 & 51,4 & 15,8 & 0,120 & 57,6 & 46,5 & 0,532 \\
\hline Cultivated Surface & 0,02 & 0,00 & 0,01 & 0,00 & 0,13 & 0,114 & 0.01 & 0.02 & 0,356 \\
\hline River Density & 0,86 & 0,93 & 0,87 & 0,88 & 1,71 & 0,051 & 0,91 & 0,99 & 0,324 \\
\hline Depth & 34,03 & 32,23 & 30,70 & 32,22 & 35,64 & 0,557 & 31,79 & 32,68 & 0,292 \\
\hline Slope & 47,03 & 47,04 & 45,05 & 50,71 & 47,09 & 0,727 & 46,46 & 50,21 & 0,453 \\
\hline Sh. Ignean Rock & 0,14 & 0,11 & 0,32 & 0,11 & 0,03 & 0,001 & 0,17 & 0,10 & 0,235 \\
\hline Sh. Metamorphic Rock & 0,14 & 0,21 & 0,25 & 0,17 & 0,16 & 0,002 & 0,22 & 0,17 & 0,000 \\
\hline Dist Colonial Roads (km) & 32,7 & 22,4 & 29,2 & 23,3 & 14,9 & 0,098 & 24,3 & 20,8 & 0,051 \\
\hline
\end{tabular}

of the cities could be influenced by the distance to the old roads that the conquerors found. In the robustness exercise, we explicitly control for the colonial roads and estimate an IV model using the colonial roads as the instrument for the location of legal capacity. 


\section{4}

\section{Empirical Strategy}

We are interested in answering whether colonial legal capacity affects or not current firms' development indicators. Also, we want to know how this persistent effect is explained. Historical state capacity investments are likely to represent different motivations of colonial authorities (Lohman, 1957; Assadourian, 1982). Nevertheless, historical accounts describe that the specific location of the state administration can be thought as an exogenous event for our specification. Therefore, our baseline model compares firms' development indicators across municipalities that had historical legal capacity and municipalities that did not have the presence of those institutions but had similar observable characteristics. In this sense, we would be able to causally interpret our coefficients. We use the 1793 census of the colonial administration to obtain information about colonial state institutions and the number of officials that were located in municipalities. Then, we are able to answer if legal capacity in the past affected firms' development using the model below.

The indicators analyzed are the formal firms per person, mean sales, mean number of workers, sales per worker, the ownership structure index and an indicator of vertical integration. Except for ownership structure index and the indicator of vertical integration, all other variables are in log form. In all cases, these variables are obtained by calculating different moments of the distribution of firms (mean and the three quartiles) for each municipality. In all cases we control for geographical, surface and climate controls, and state level dummies.

$$
Y_{m}^{j}=\alpha_{m}^{j}+\beta_{1}^{j} H L C_{m}+\phi_{1}^{j} X_{m}+u_{m}^{j}
$$

Where $Y_{m}^{j}$ is the indicator $\mathrm{j}$ of firms' development in municipality $\mathrm{m}$, $H L C_{m}$ is the historical measure of legal capacity in municipality $\mathrm{m}$, and $X_{m}$ is a set of municipality level controls. As our focus is on the legal capacity of the state, we should take into account the public provision of goods and services as a potential source of bias. In this line, we use the distance to colonial roads to control for the fiscal state capacity of the state. Later, we add other relevant social variables as additional controls to rule out alternative hypotheses, highlighted by the literature, driving our results. We compute 
spatially corrected standard errors in both models given the nature of the problem.

In a second exercise, we evaluate the relative importance of one specific institution of our legal capacity index, the presence of courts. Then, we use a similar specification of equation (4-1), but we change $H L C_{m}$ for our dummy variable representing the presence of colonial courts. The robustness exercise will evaluate the stability of the coefficient when the other institutions of legal capacity are included, and when we include the other important controls mentioned too. Finally, we use the same specification to perform our preliminary analysis of informal and formal norms using firms' perceptions of the relationship with the state.

A second important question is how this persistence can be explained. We test the hypotheses that the colonial distribution of state presence is persistent in time when we consider a country with poor fiscal capacity (16). In this sense, we analyze if historical legal capacity affected the current distribution of legal capacity along the territory. Here $C L C_{m}$ is the current legal capacity index. We directly control for colonial roads and the other relevant socioeconomic covariates mentioned earlier. Similar to the first case, we analyze the relative importance of the colonial court's dimension in a similar specification.

$$
C L C_{m}=\rho_{s}+\gamma H L C_{m}+\phi_{2} X_{m}+\epsilon_{m}
$$

Finally, as a robustness exercise on the specification of our model, we evaluate our theory using an IV approach and a network setting as in (3). In our IV method, we use the historical presence of legal capacity and the distance to colonial roads as instruments for the current presence of legal capacity and the current distance to roads. Also, as mentioned in the balance of geographic characteristics, we use colonial roads as the instrument for historical legal capacity. Finally, in our network setting, we use a weighting adjacency matrix to evaluate the effect of colonial legal capacity on neighbors. 


\section{Results}

\section{1}

\section{Historical legal capacity presence and Firms' development}

Here we present our baseline results on the persistent effects of the historical presence of legal capacity on firms' development indicators. We report the effect of colonial legal capacity, and specifically, colonial courts in table 5.1. Our results show that the places where Spaniards created legal institutions in general, and town halls in specific, now are places where firms are less vertically integrated. This means that in those places firms prefer to make transactions through the market. As (37) argues, this represents an improvement in the use of resources. To understand the coefficient observed, imagine a firm that sales 500 tax units in a year and $0.7 \%$ of them are produced within the firm (351 tax units). If the Spaniards had created legal capacity in that municipality, firms would buy from market 10 tax units, for each additional dimension of the index, instead of producing it internally. Moreover, if Spaniards had created a town hall, firms would buy from market 24 tax units instead of producing it internally.

Related to ownership structure, we do not observe a significant effect of colonial legal capacity. Then, those places with historical legal institutions do not have firms that use the State services to create more complex organizations. In spirit, a collective ownership structure is used as an alternative way to collect capital for investments and to diversify the risk of your investments. The null result observed can be explained by two facts. First, the insufficient development of markets in Peru. There are not a well-developed stock markets decentralized in all the regions of Peru, the only stock market is located in Lima, the capital of Peru. Second, as a consequence of the first fact, firms may rely more on demanding credit from the financial sector to obtain capital for investments.

Third, we observe positive and significant effects on the size and productivity level in those places with historical legal capacity. To illustrate the magnitude of the effects obtained, the establishment of legal capacity would imply an increase of two workers in the mean size of its firms. Moreover, the 
establishment of a colonial court would represent an increase of 5 additional workers in the mean size of the firm. When we look at our productivity indicator, the establishment of legal capacity represents an increase of 7.5 tax units in sales per worker for a representative firm in the municipality. Also, the establishment of colonial courts represents an increase of 18.5 tax units in sales per worker. We obtain similar results to the ones obtained by (43) and (35) regarding the relationship between firms' size and the legal system's quality. As we will show below, our treated municipalities have fewer restrictions to access to formal credit, related to gains in size by the literature. Also, we presume that firms in municipalities with colonial legal capacity had a faster transition to the lognormal distribution, studied by (14), which reflects the observed gains in size.

Finally, we observe a significant increase in the number of formal firms per capita for our treated municipalities. For a municipality of 10 thousand inhabitants with 380 formal firms operating (these numbers represent the mean value of the variable), if Spaniards had established legal capacity in the past, then the municipality would have 9 additional formal firms. Moreover, if they had created colonial courts, then there would be 28 additional formal firms. We may complement this specific analysis using additional information on industrial concentration as the observed number of formal firms is a general equilibrium result of market competition. 


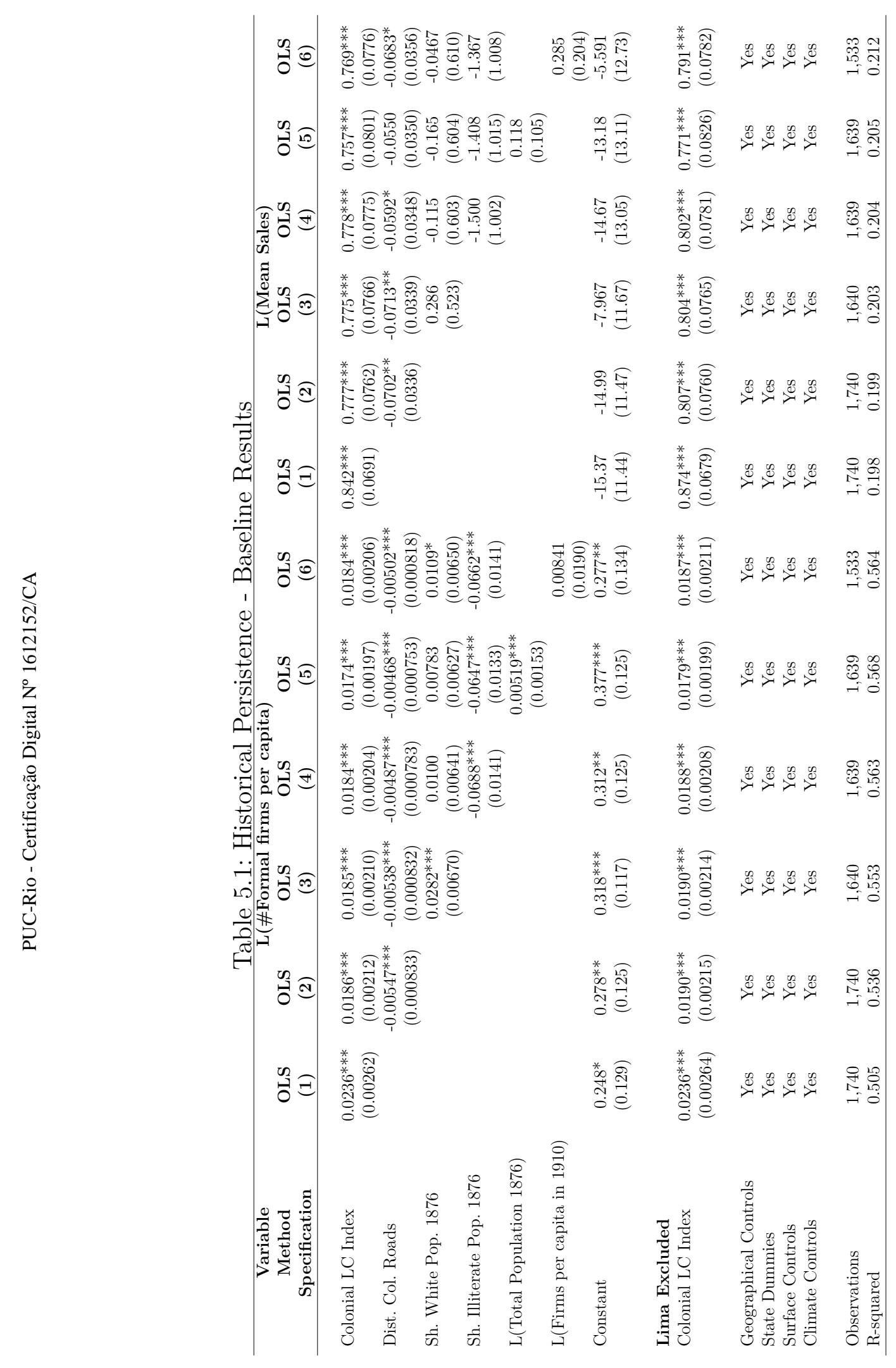




\section{2}

\section{Alternative explanations}

In this section, we evaluate the plausibility of our hypotheses by contrasting it with other potential explanatory histories highlighted by the literature. We test our baseline results in columns 1 of tables tables 5.2, 5.3 and 5.4; with the addition of critical socioeconomic variables obtained from historical sources. For all tables, Columns 2 add the distance to colonial roads, the main public good provided by the colonial administration, to control for the fiscal capacity of the state. Our results show a comprehensive negative relationship between the distance to the colonial roads and the firms' development indicators Our estimates for all specifications are quite stable. Moreover, for two municipalities at the same distance to the colonial roads, the magnitude of the effect of legal capacity is quite stable and significant. This first exercise gives us confidence that we are actually measuring the legal capacity and not other dimensions of the state.

We explored other alternative hypotheses that could totally explain our results on the persistence of historical legal capacity. We analyze three main hypotheses related to the racial distribution of the population, human capital and initial conditions for market development.

For all tables, column 3 adds the share of white people as an additional control to test the importance of the racial distribution in 1876 (the relative composition between white and indigenous people). In theory, a higher share of whites could explain the observed results in market development in two ways. First, it would represent a higher share of the group with more political power in their demands to the central State for public goods or changes in the legal framework. Second, following (9), (36) or (48); a city with more ethnic fragmentation or heterogeneous cultural norms is associated with more conflict and an inefficient provision of public goods. Both dimensions are important for the development of the market and the creation of firms. In Peru, (17) mentions the little economic interaction between the indigenous people with the rest of the population. Our results show a positive relationship between the share of whites and economic indicators of firms supporting the arguments mentioned. However, the colonial legal capacity, and colonial courts, variables are quite stable to the addition of this rival explanation. Then, for two municipalities with similar racial distribution in their populations, legal state capacity has a positive and significant effect on firms similar to the results above. 


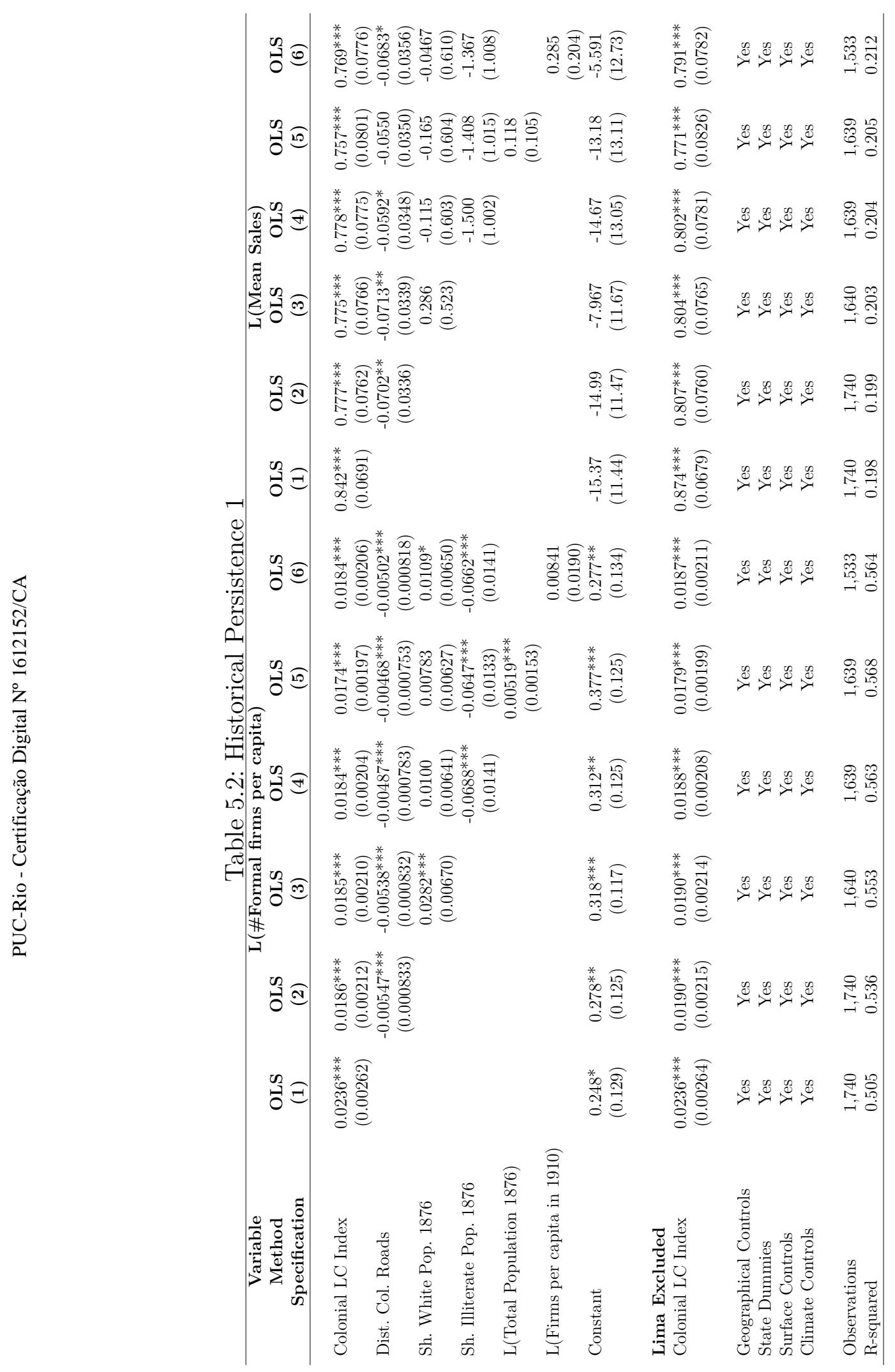




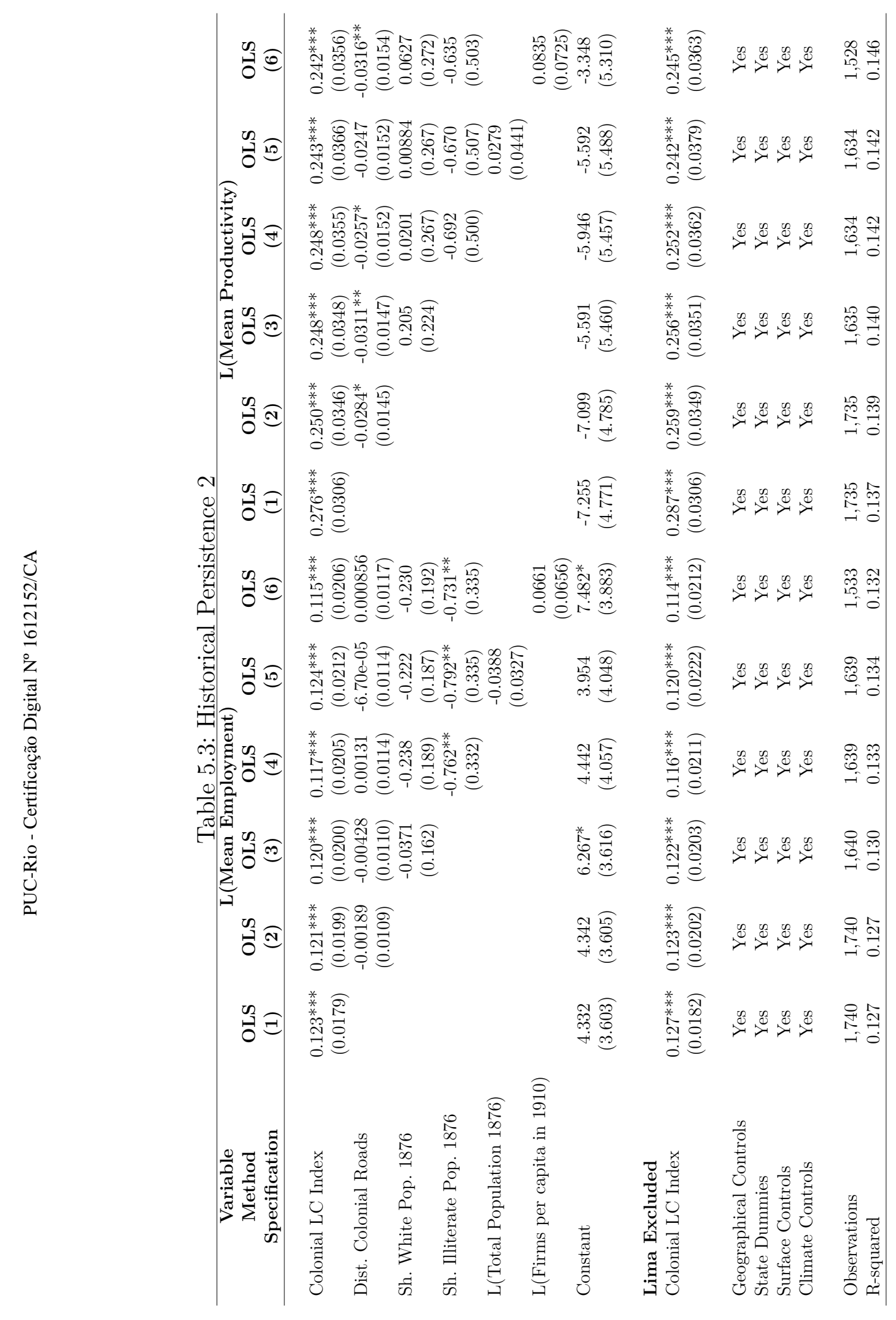




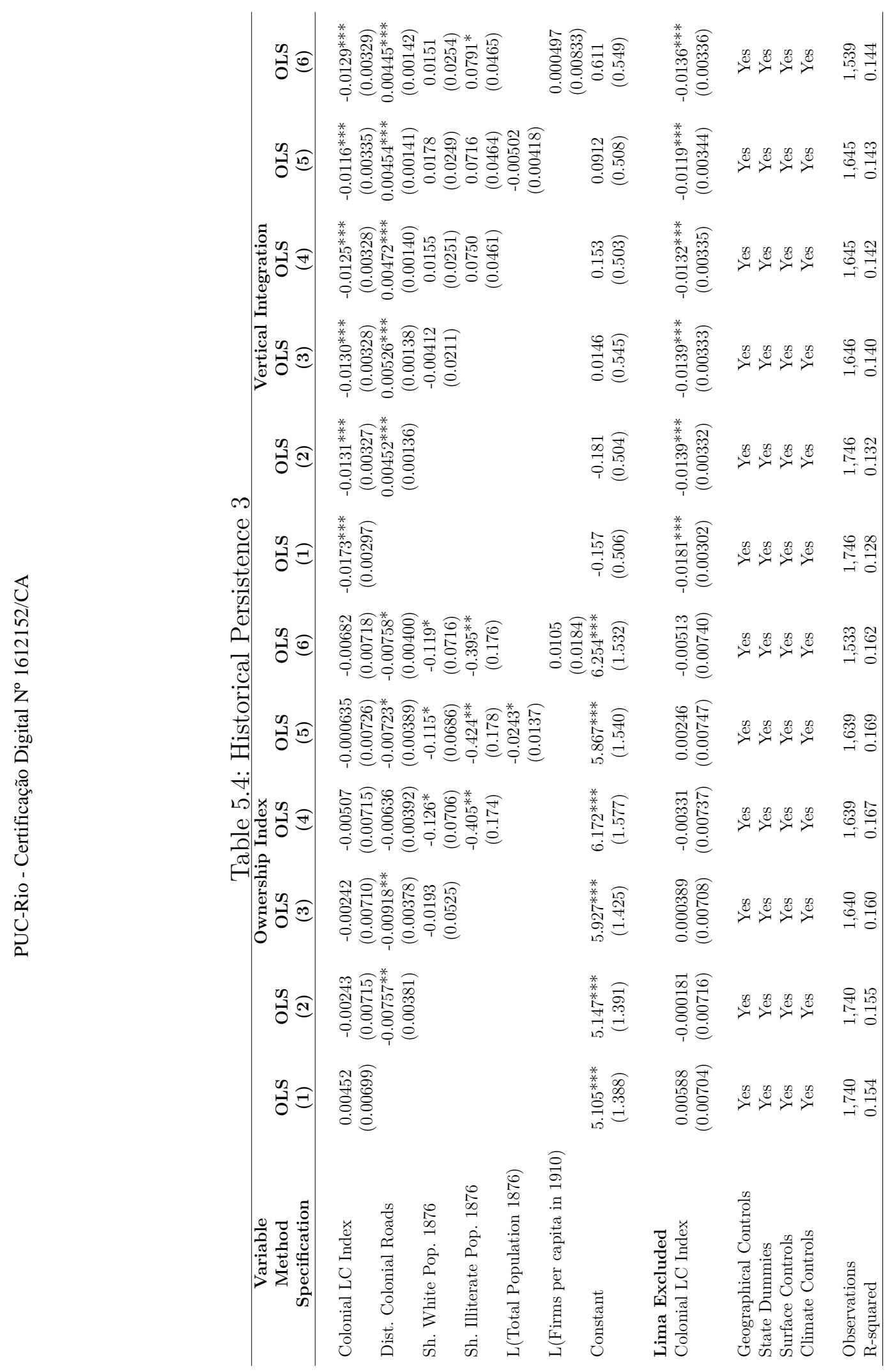


Second, we control for the literacy rate in 1876, a good approximation for human capital in that period. These hypotheses test whether human capital features could confound the effect of legal capacity in the colony. Literature emphasizes the importance of human capital to explain the differences observed in economic development (27). Also, (46), (40) and (52); highlights the persistent effects of historical human capital to explain current differences in development. It is plausible that those places where the majority of the population could read and write have a better environment for market development. Results show a negative relationship between the illiteracy rate and our firms' development indicators, which is consistent with the previous findings. Surprisingly, the coefficient obtained for historical legal capacity continues to be highly stable relative to the baseline result. Then, for two municipalities with similar illiteracy rates in their populations, legal state capacity has a positive and significant effect on firms quite similar to the ones observed above.

Third, we must consider the initial conditions for market development as we are dealing with firms. We obtain information on the total population in 1876 and the number of formal firms in the 1910s to measure this important dimension. There are two important channels that may encourage the development of markets. First, those places with more population represent an important demand that may promote the creation and development of firms. Second, the initial distribution of firms represents potential economies of scale and agglomeration that naturally arise in the development of markets. Then, those places with an initial higher number of firms may stimulate more concentration of them. Consistent with the previous reasoning, the results show that both variables, the total population and the number of formal firms per capita, are positively associated with the development of firms. Municipalities with more population encourage more market development, and agglomeration economies are more likely to originate and persist in this populous municipalities. Surprisingly, the coefficient of historical legal capacity, and colonial courts continues to be highly stable and is not significantly different from the ones obtained in the baseline model. Finally, our results rule out potential problems associated to reverse causation. Courts and other legal capacity institutions may have been placed in those municipalities with initial concentrations of firms or producers. Nevertheless, as we have shown, our results do not support this claim.

In addition, we may suspect that all our results are driven by big cities where the large corporations operate. Nevertheless, for all our specifications, our results are consistent to the inclusion or exclusion of big cities like Lima. 
Lima represents nearly $30 \%$ of Peruvian population and nearly $40 \%$ of Peruvian GDP. Then, our results are not driven by the most developed city in the sample. Furthermore, the results are quite similar to the ones obtained in the full sample for all the specifications analyzed.

Fifth, as in our baseline estimations, we evaluate the relative importance of the dimensions considered in our legal capacity index. We estimate our model including indicators for the historical presence of courts; and "Escribanos", "Gendarmerie" and post offices; independently. We present these results in tables 5.5, 5.6 and 5.7. Results show that the historical presence of courts is a quite important dimension of our legal capacity index. Its effect is larger and significant in the majority of cases than the other dimensions of our colonial legal capacity index. Furthermore, the coefficients obtained are robust and highly stable when we test all previous hypotheses mentioned earlier. Our results contribute to the discussion on the relative importance of legal institution for development ((35), (23) and (2)), by showing that courts are quite relevant in a specific dimension of development, the firms' development. 


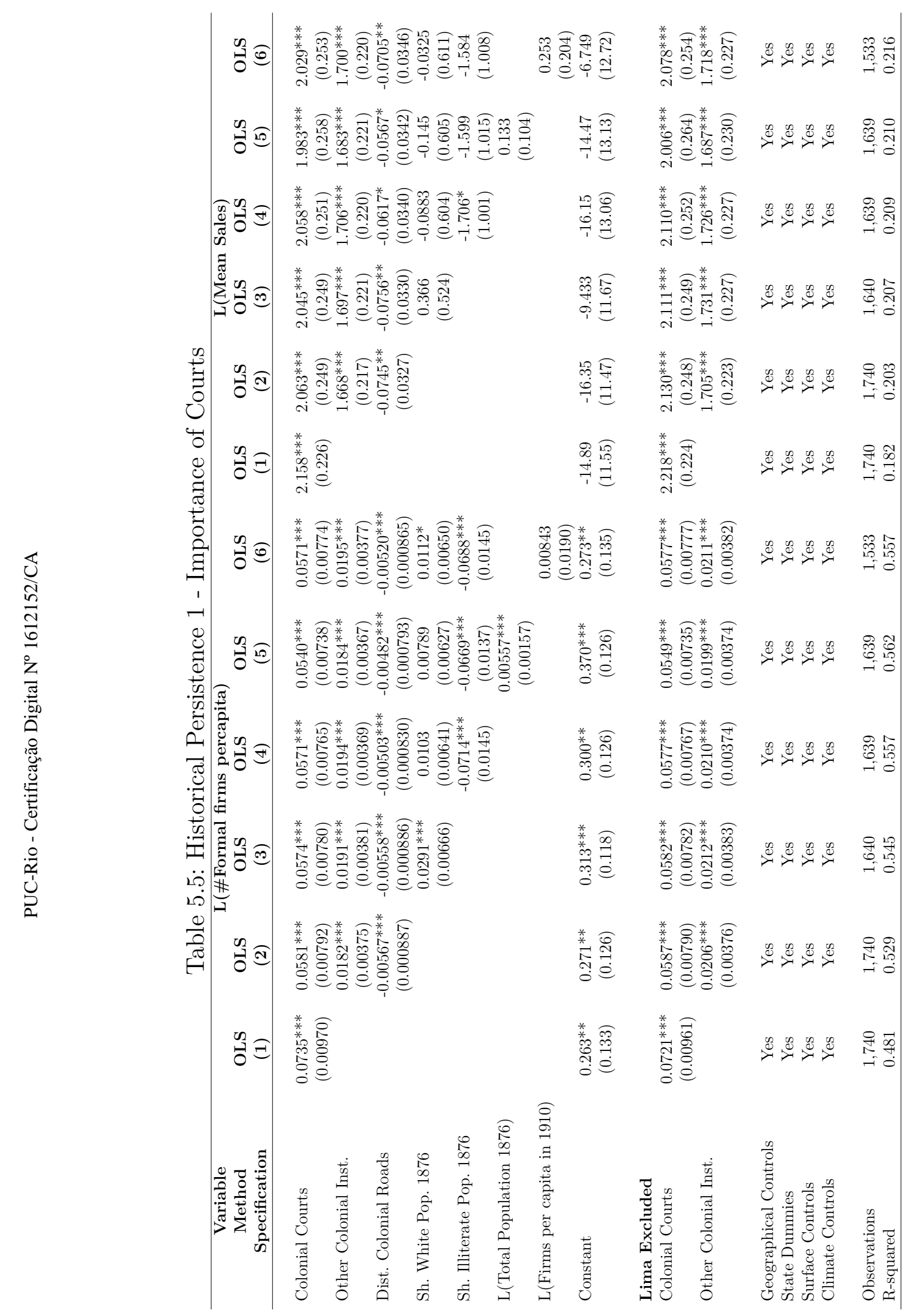




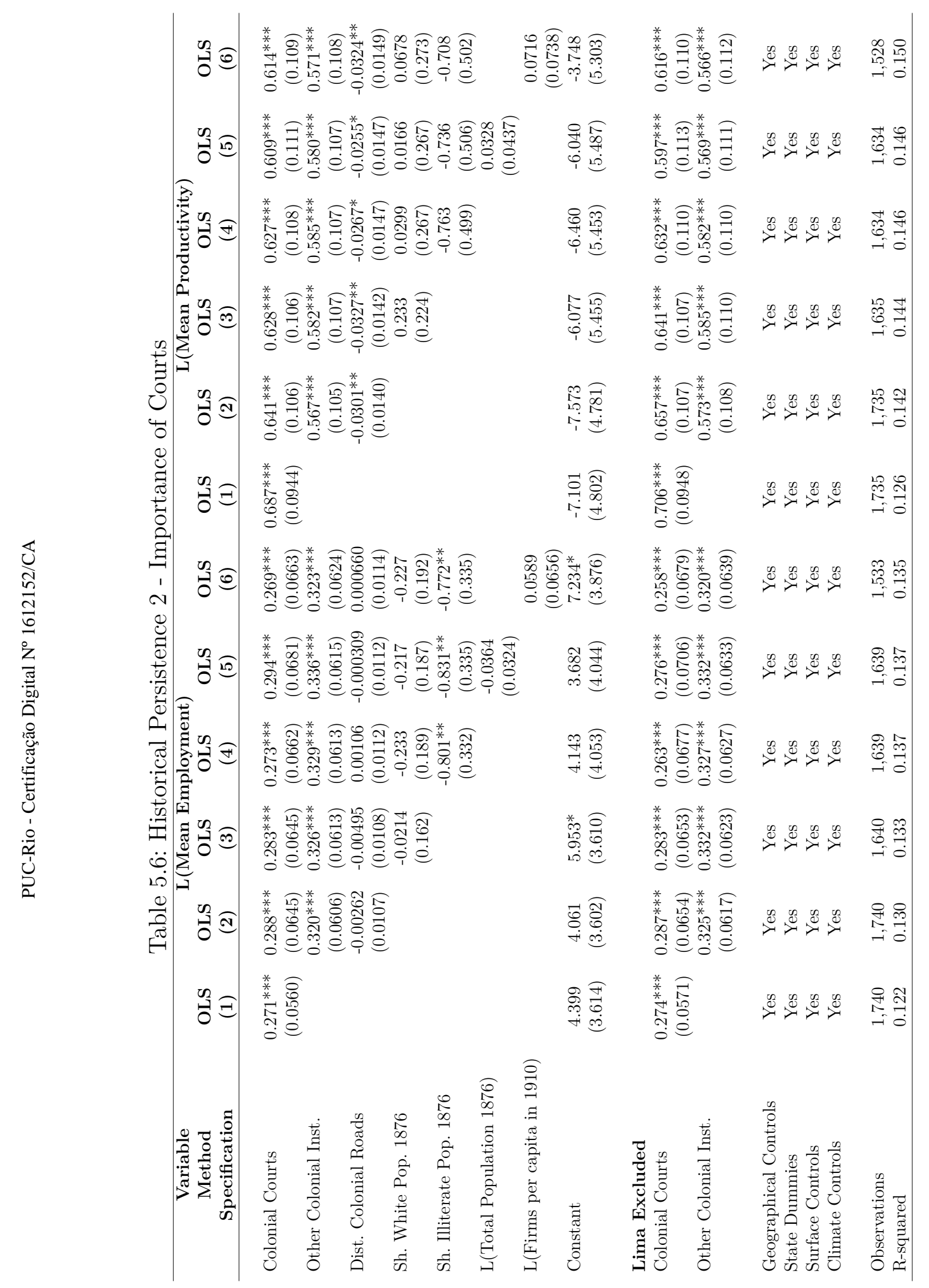




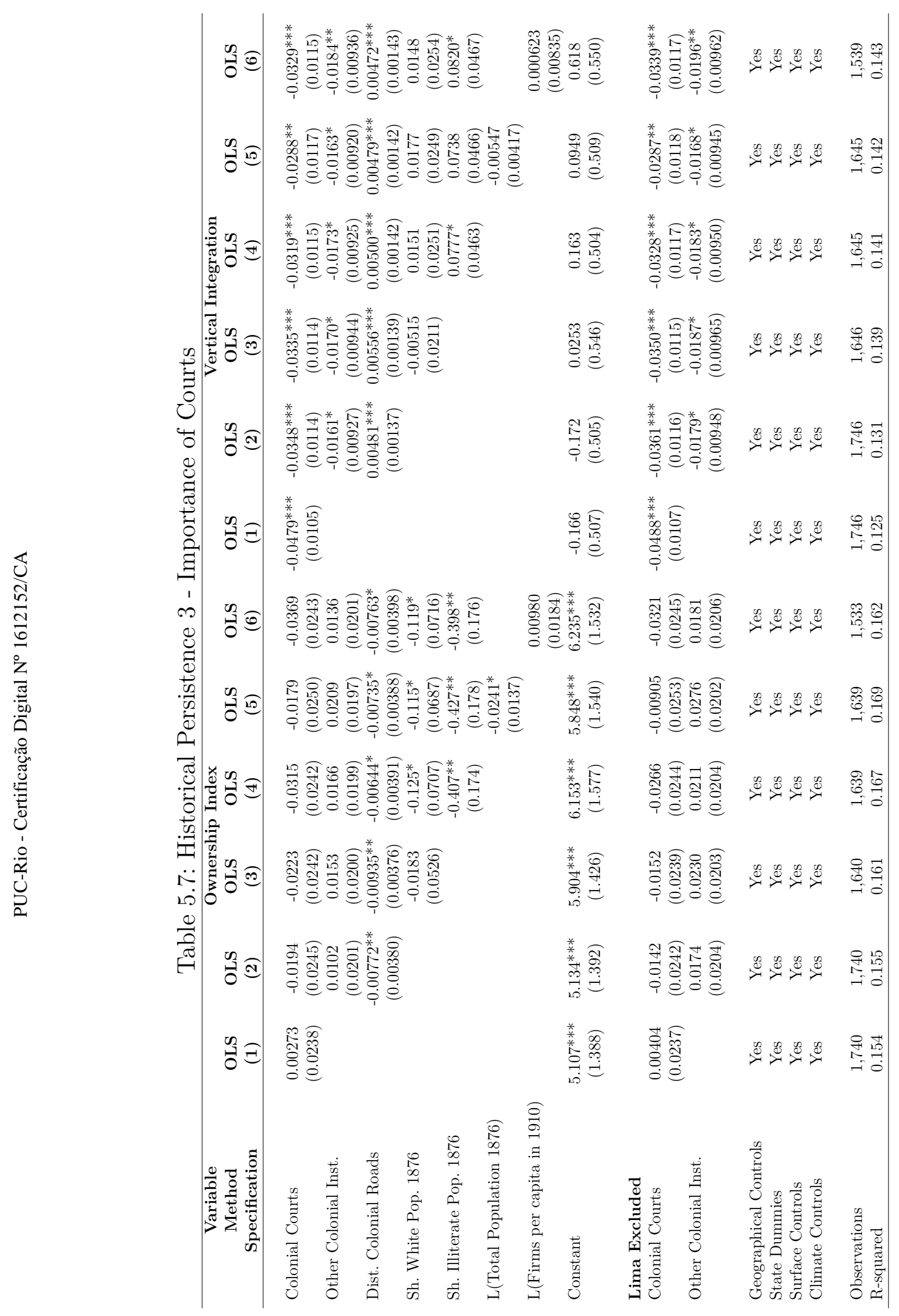


Table 5.8: Historical Persistence - Sectoral Analysis

\begin{tabular}{|c|c|c|c|c|c|c|}
\hline $\begin{array}{l}\text { Variables } \\
\text { Methods } \\
\text { Specifications }\end{array}$ & $\begin{array}{c}\text { L(\# Formal Firms pc) } \\
\text { OLS } \\
(7)\end{array}$ & $\begin{array}{c}\text { L(Sales) } \\
\text { OLS } \\
(8)\end{array}$ & $\begin{array}{l}\mathrm{L} \text { (Workers) } \\
\text { OLS } \\
(9)\end{array}$ & $\begin{array}{c}\mathrm{L} \text { (Sales/Workers) } \\
\text { OLS } \\
(10)\end{array}$ & $\begin{array}{c}\text { Ownership Index } \\
\text { OLS } \\
(11)\end{array}$ & $\begin{array}{l}\text { Vert. Integ. } \\
\text { OLS } \\
(12)\end{array}$ \\
\hline Hist. LC Index & $\begin{array}{c}0.0135^{* * *} \\
(0.00150)\end{array}$ & $\begin{array}{c}0.551^{* * *} \\
(0.0594)\end{array}$ & $\begin{array}{c}0.0741^{* *} \\
(0.0256)\end{array}$ & $\begin{array}{c}0.174^{* * *} \\
(0.0276)\end{array}$ & $\begin{array}{l}0.00517 \\
(0.0160)\end{array}$ & $\begin{array}{c}-0.00967^{*} \\
(0.00395)\end{array}$ \\
\hline $\begin{array}{l}\text { Obs. } \\
\text { R2 }\end{array}$ & $\begin{array}{l}5,817 \\
0.318\end{array}$ & $\begin{array}{l}5,817 \\
0.268\end{array}$ & $\begin{array}{l}5,817 \\
0.249\end{array}$ & $\begin{array}{l}5,817 \\
0.187\end{array}$ & $\begin{array}{l}5,817 \\
0.422\end{array}$ & $\begin{array}{l}3,242 \\
0.639\end{array}$ \\
\hline $\begin{array}{l}\text { Hist. Courts } \\
\text { Hist. Police and PostOff }\end{array}$ & $\begin{array}{l}0.0415^{* * *} \\
(0.000526) \\
0.0126^{* * *} \\
(0.000393)\end{array}$ & $\begin{array}{c}1.322^{* * *} \\
(0.207) \\
1.032^{* * *} \\
(0.155)\end{array}$ & $\begin{array}{c}0.279^{* * * *} \\
(0.0894) \\
0.209^{* * *} \\
(0.0667)\end{array}$ & $\begin{array}{c}0.501^{* * * *} \\
(0.0965) \\
0.405^{* * *} \\
(0.0720)\end{array}$ & $\begin{array}{c}0.0349 \\
(0.0559) \\
0.0283 \\
(0.0417)\end{array}$ & $\begin{array}{c}-0.0309^{* * *} \\
(0.0139) \\
-0.0194^{*} \\
(0.0104)\end{array}$ \\
\hline $\begin{array}{l}\text { Obs. } \\
\text { R2 }\end{array}$ & $\begin{array}{l}5,817 \\
0.317\end{array}$ & $\begin{array}{l}5,817 \\
0.269\end{array}$ & $\begin{array}{l}5,817 \\
0.252\end{array}$ & $\begin{array}{l}5,817 \\
0.188\end{array}$ & $\begin{array}{l}5,817 \\
0.423\end{array}$ & $\begin{array}{l}3,242 \\
0.639\end{array}$ \\
\hline $\begin{array}{l}\text { Geographical Controls } \\
\text { Surface Controls } \\
\text { State Dummys } \\
\text { Climate Controls } \\
\text { Sectoral Dummys }\end{array}$ & $\begin{array}{l}\text { Yes } \\
\text { Yes } \\
\text { Yes } \\
\text { Yes } \\
\text { Yes }\end{array}$ & $\begin{array}{l}\text { Yes } \\
\text { Yes } \\
\text { Yes } \\
\text { Yes } \\
\text { Yes }\end{array}$ & $\begin{array}{l}\text { Yes } \\
\text { Yes } \\
\text { Yes } \\
\text { Yes } \\
\text { Yes }\end{array}$ & $\begin{array}{l}\text { Yes } \\
\text { Yes } \\
\text { Yes } \\
\text { Yes } \\
\text { Yes }\end{array}$ & $\begin{array}{l}\text { Yes } \\
\text { Yes } \\
\text { Yes } \\
\text { Yes } \\
\text { Yes }\end{array}$ & $\begin{array}{l}\text { Yes } \\
\text { Yes } \\
\text { Yes } \\
\text { Yes } \\
\text { Yes }\end{array}$ \\
\hline
\end{tabular}

Finally, we evaluate the importance of some sectors to explain our results. Then, we estimate the model at the sector-municipality level and include sectoral dummies to analyze whether the effects observed in the previous tables are driven by specific sectors or not. In all cases, we only consider the sectormunicipality units that have more than 5 formal firms observed. Table 5.8 shows that the effects obtained in the baseline estimations are a general pattern observed across sectors. It is worth mentioning that there is a general reduction in the estimates of the five variables given the addition of the sectoral dummies. As an overall picture, those municipalities with more legal capacity are places where the institutions of markets and firms seem to perform better.

\section{3}

\section{The persistence over time}

In order to trace down the persistence of historical legal capacity institutions, we collected firm-level data from the Registry of the industrial sector in 1954 from the Ministry of Production. We processed data on the number of formal firms per capita and the mean size of firms for each municipality.

The specifications estimated are the same than in our previous estimates. We evaluate the effect of historical legal capacity presence controlling for the share of white people, the share of illiterates, the total population in 1876 , and the initial conditions of firms development in the 1910s. We present our results in tables 5.9 and 5.10. The coefficient values for nearly all the variables are in line with our previous main specifications. In general, the coefficients obtained for the number of formal firms per capita and the mean size of the firms are higher which suggest that persistence decay in time. Our estimates are highly stable to the addition or exclusion of the metropolis Lima too. 


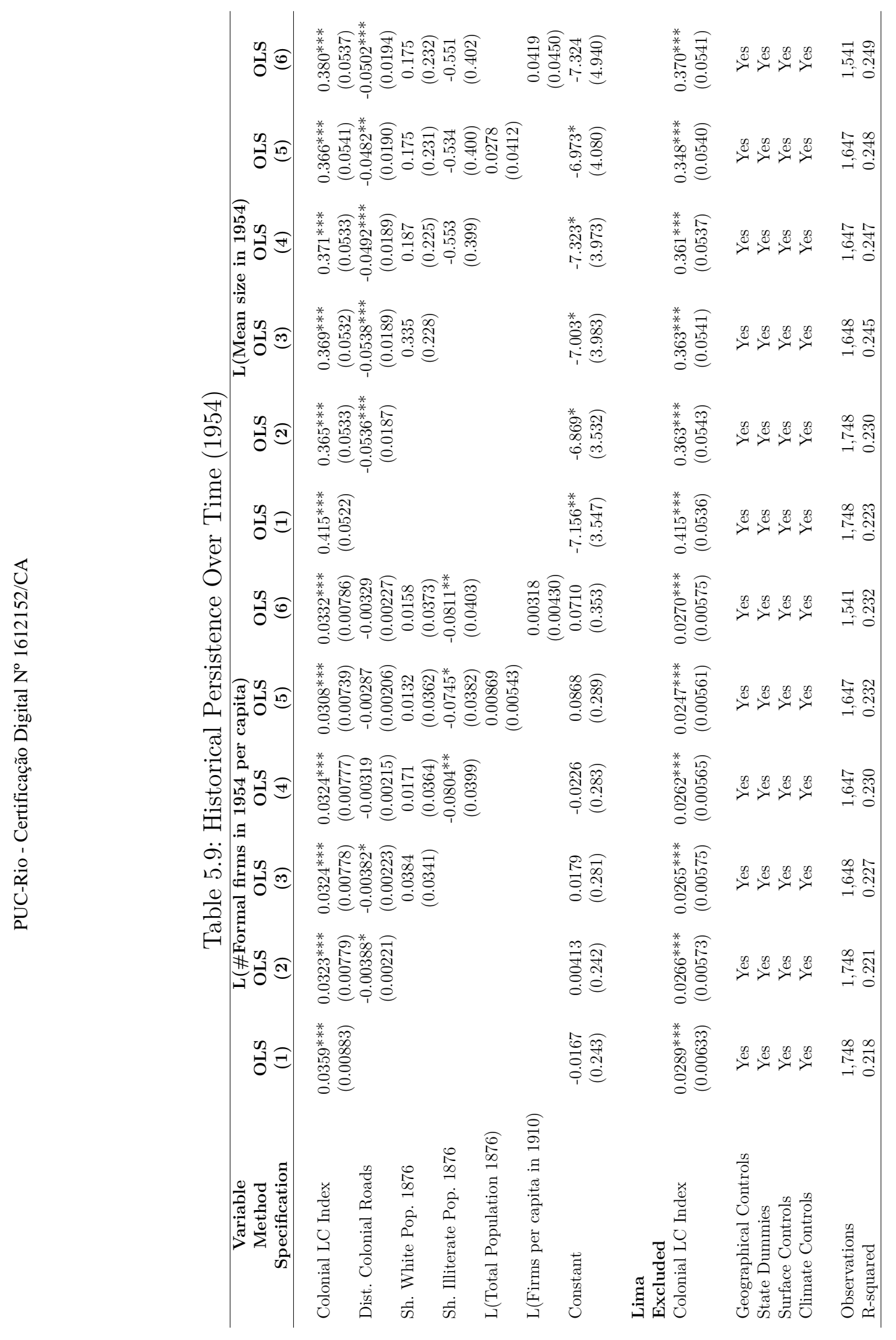




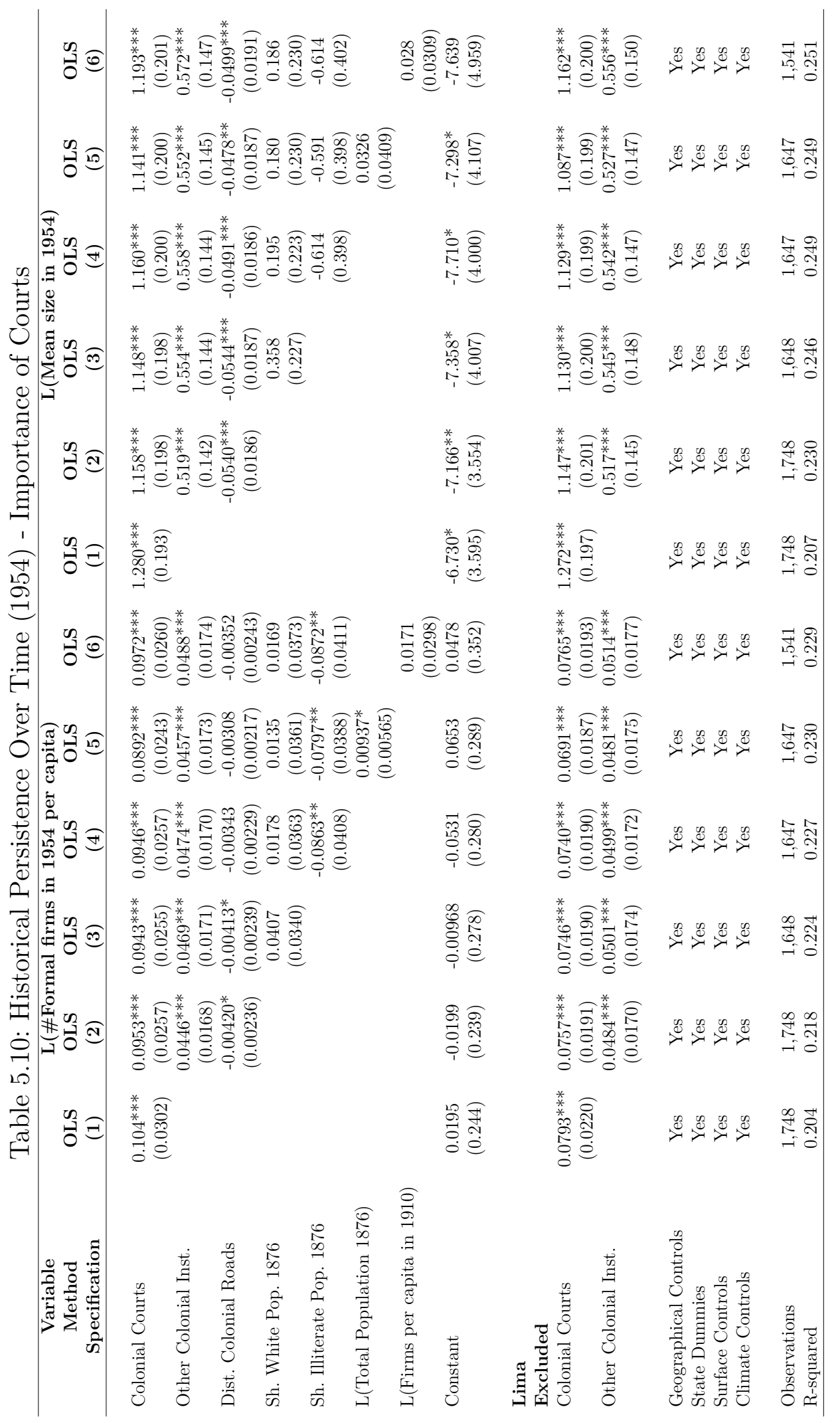


This exercise gives us confidence that our results are not been affected by idiosyncratic time specific shocks.

\section{4}

\section{Legal capacity persistence}

Next, we evaluate the second question posed, does historical legal capacity, a specific dimension of state capacity, is persistent in time? (23) made an extensive study relating the establishment of a legal system and the general procedures needed in two standard judicial cases. Results showed that civil law countries had more formal procedures than other legal systems. Moreover, those countries that obtained their legal system by transplantation had more formal procedures within the civil law group. Procedural formalism was associated with an inefficient practice of justice and was negatively associated with economic development. Here, we want to expand this evidence to understand the determinants of the heterogeneity in the practice of justice within a civil law country. As a first step, we begin by analyzing whether legal capacity presence is persistent or not. Later improvements to this section would trace persistence in courts, production of judges and perceptions on judicial procedures.

In table 5.11 we present the baseline results of the estimation of legal capacity persistence. Our baseline estimation shows that the colonial distribution of legal capacity is highly persistent regarding the current distribution of legal capacity. We use the same earlier specifications to evaluate the stability of the index. As in our baseline model, we control for social characteristics obtained from the 1876 population census and the initial level of firms in the 1910s. In all cases, the marginal effects are positive and precisely estimated. Indeed, those places with historical state capacity near the end of the colonial period, are the same places where rule of law was enforced during the republican period. 


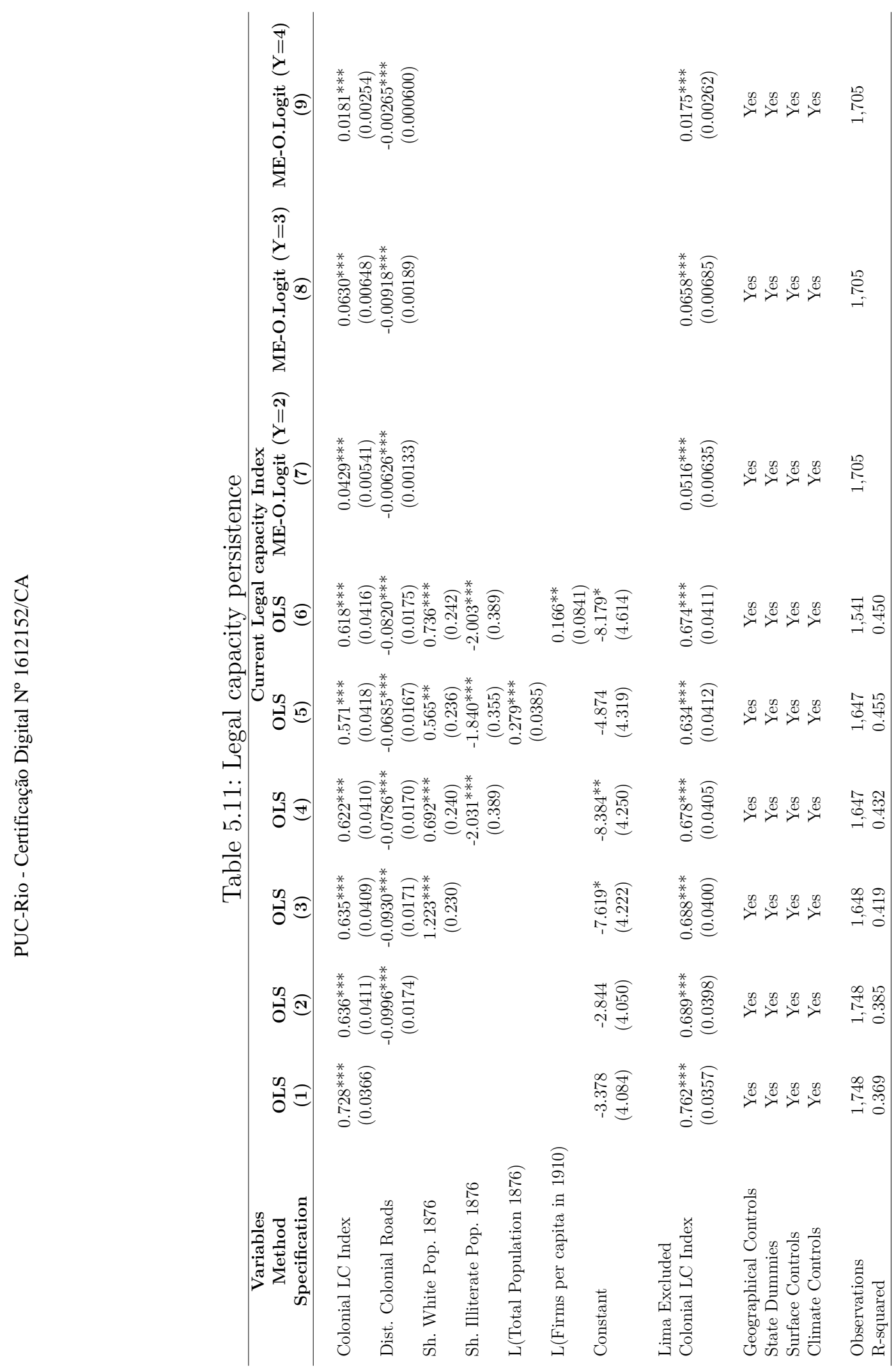


Table 5.12: Legal capacity transition matrix

\begin{tabular}{lccccc}
\hline $\begin{array}{l}\text { Variable } \\
\text { Method }\end{array}$ & $\begin{array}{c}\text { LC=1 } \\
\text { OLS }\end{array}$ & $\begin{array}{c}\text { OLS } \\
\text { OLS }\end{array}$ & $\begin{array}{c}\text { LC=3 } \\
\text { OLS }\end{array}$ & $\begin{array}{c}\mathbf{L C}=\mathbf{4} \\
\text { OLS }\end{array}$ & $\begin{array}{c}\mathbf{L C}=\mathbf{5} \\
\text { OLS }\end{array}$ \\
\hline \multirow{3}{*}{ Past LC=1 } & $0.282^{* *}$ & $0.492^{*}$ & 0.161 & -0.245 & -0.307 \\
& $(0.123)$ & $(0.263)$ & $(0.420)$ & $(0.567)$ & $(0.718)$ \\
Past LC=2 & 0.0712 & $0.244^{*}$ & 0.222 & -0.0812 & -0.102 \\
& $(0.0670)$ & $(0.143)$ & $(0.228)$ & $(0.309)$ & $(0.391)$ \\
Past LC=3 & 0.0333 & 0.0800 & $0.640^{* *}$ & 0.140 & -0.0333 \\
& $(0.0758)$ & $(0.162)$ & $(0.258)$ & $(0.349)$ & $(0.442)$ \\
Past LC=4 & -0.000 & 0.000 & 0.000 & $0.875^{* * *}$ & $1.250^{* * *}$ \\
& $(0.0528)$ & $(0.113)$ & $(0.180)$ & $(0.243)$ & $(0.308)$ \\
\hline
\end{tabular}

Our results highlight an important mechanism behind the persistent effects of legal capacity on firms. Colonial legal capacity presence affects firms' development indicators because it persists to the current distribution of legal capacity. Our hypotheses relate historical legal capacity with a change in the relative costs of subsequent investments in creating more state capacity. This premise is quite relevant for weak states. In a recent paper of (5), when local elites have no counterbalance in civil society, elites have no incentives to expand state capacity. This is a relevant proposition for the Peruvian case where there were not significant collective movements for a more democratic distribution of political and economic power.

In addition, as we are dealing with indices as variables, we would like to estimate a probability model as a robustness exercise on the specification form. Then, we use an ordered probit to evaluate the marginal effects of historical presence on the probability of having more legal capacity enforcement in the present. Results go in the same direction, a positive and significant marginal effect on the probability evaluated at $Y=2, Y=3$ and $Y=4$.

As a third exercise to analyze legal capacity persistence, table 5.12 presents the transition matrix between the colonial and current indices. The matrix shows a clear persistence in every value of the indices. This results give internal consistency to the relation between indices and give more confidence in the hypotheses we advanced.

The set of results observed allowed us to argue that the colonial distribution of state presence was persistent in time because it changed the relative costs of subsequent investments to create new state capacity or increase the existing presence. This argument is corroborated by several historical accounts from the early republic. (11) and (49) point out that, between 1822 and 1854, the same colonial institutions (Governor, Sub-Delegate, and Mayor) acquired the authority to rule on legal matters and/or controversies. Another example related to persistence of the colonial state administration is described by (16). 
He describes the enormous difficulties to raise taxes at the beginning of the republic. The central state had to rely on previous colonial institutions like departmental officials to delegate them the authority of collecting taxes. The combination of an irregular and weak initial state and the poor incentives that elites had to build up more state capacity, explain the persistence of these colonial institutions. Then, colonial courts were justice satellites for each province.

\section{5}

\section{Alternative specifications}

We gave evidence that the colonial distribution of state presence was persistent in time because it changed the relative costs of subsequent investments to create or increase state capacity in a country led by an initial weak state. As we mentioned, by the time of the colonial period, the specific location of the places elected to set up the colonial state capacity should be driven by idiosyncratic factors. As a robustness exercise on the model specification, we can structure our findings in an IV model where current legal capacity is instrumented by colonial legal capacity, and distance to current roads is instrumented by the distance to colonial roads. We present these results in column 2 of tables 5.13 and 5.14. We use the results in the previous section as our first stage estimation. The results go in the same direction to the ones obtained in the baseline model. In all cases, we have a positive and significant effect of legal capacity on firms' development indicators.

Besides, we mentioned in the historical background that the foundation of cities, and the colonial institutions within them, may have been influenced by the distance to colonial roads. Then, in column 3 we present the results of an IV model where we use colonial roads as the instrument for our colonial legal capacity index. Results on the first stage show that colonial roads could be an additional factor considered in the foundation of new cities. Again, we obtain a positive relationship between colonial legal capacity and firms' development indicators.

Exclusion restrictions are hard to defend even after the robustness checks we tested above. We would need further evidence that supports that colonial legal state capacity affects current indicators of firms' development only through its effect on current legal capacity. Moreover, for our IV specification in column 3, we would need to defend the implausible argument that colonial roads affect firms development only through its effect on legal capacity. We have already used it as a good instrument of the current distribution of roads. 


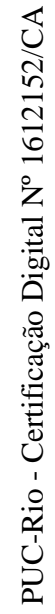




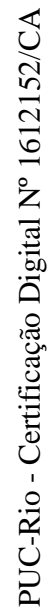

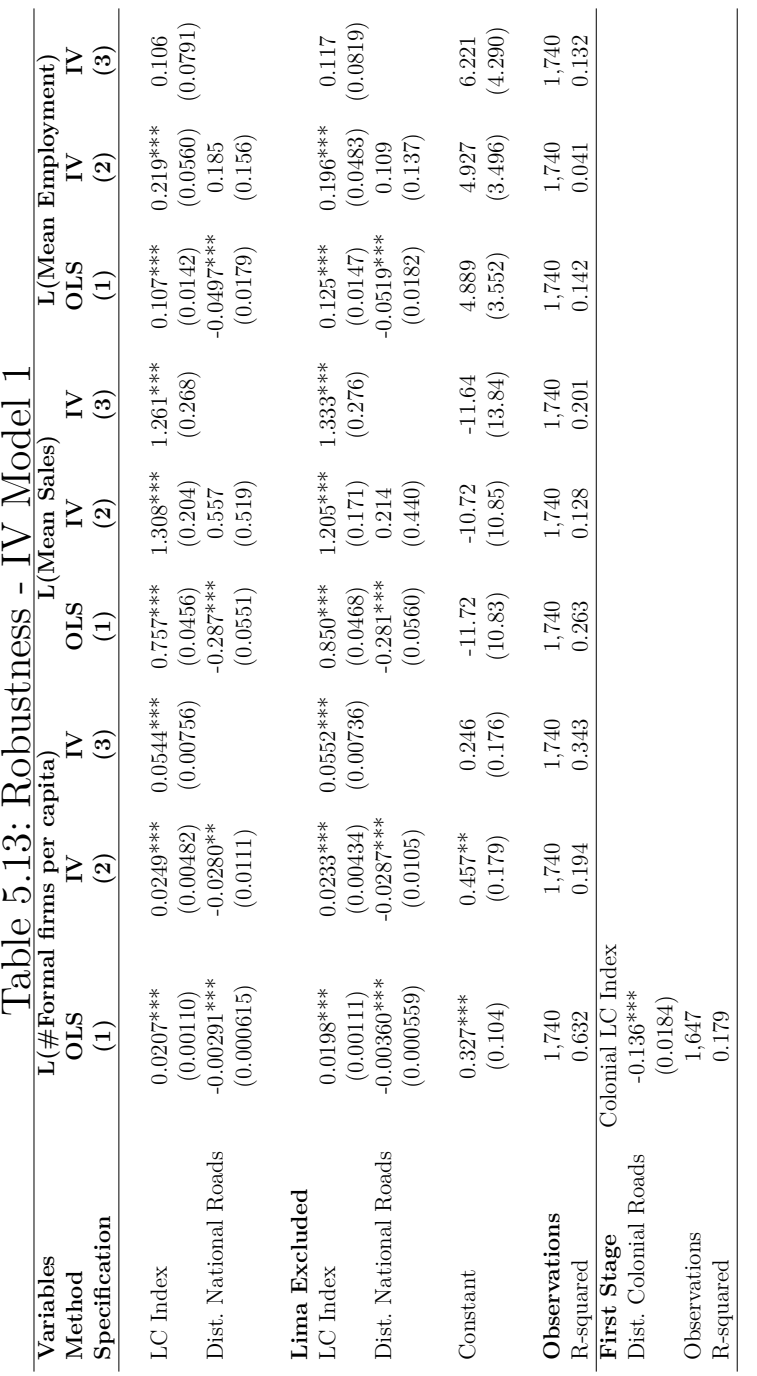




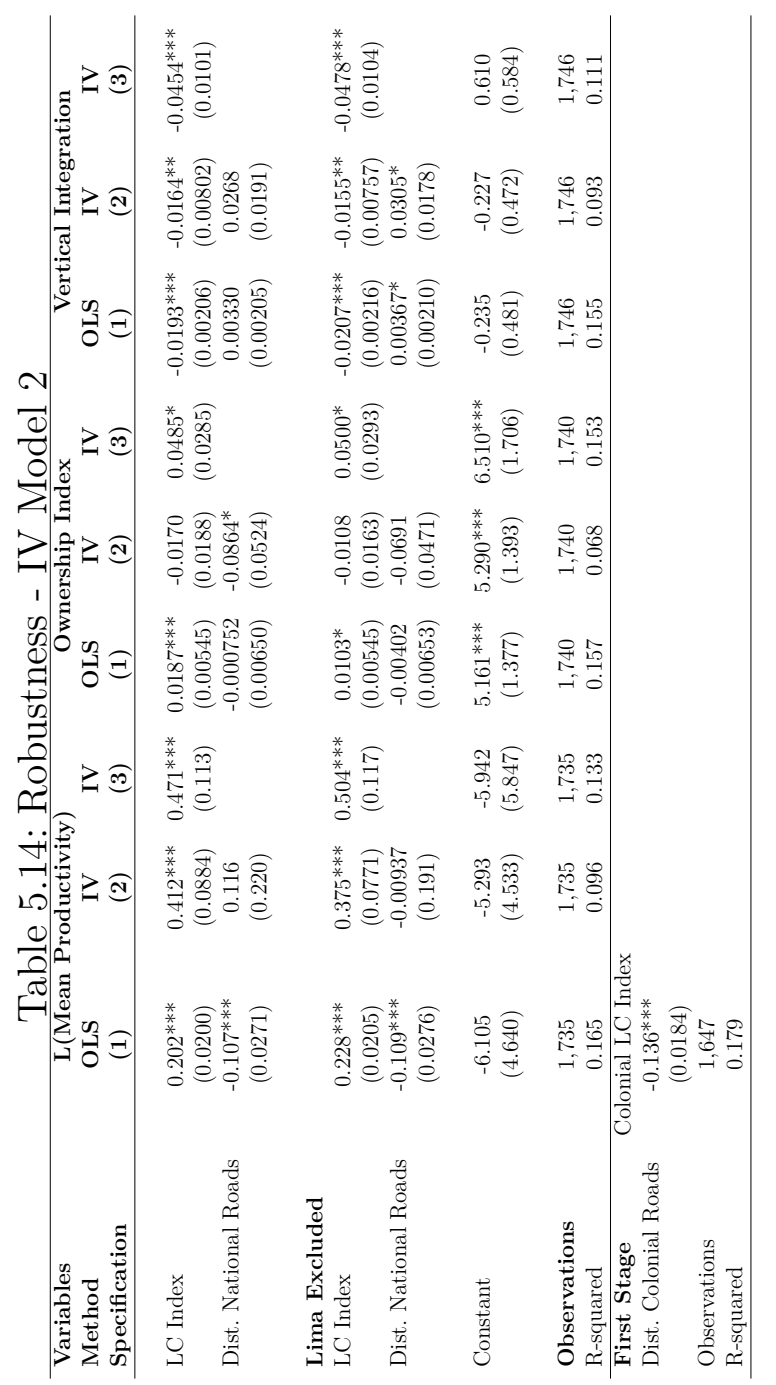


A second exercise is focused on the network effects. Following (3) we analyze the direct and spillover effects of the historical legal capacity distribution in a network framework. We do not use the game-framework proposed in (3) because Peru was historically a highly centralized country where all decisions on state capacity formation were held in Lima (15). We identify the set of neighbors of a municipality as the set of all the municipalities adjacent to its territory. Also, we measure the intensity of the relationship as a function of distance and difference in elevation between nodes. Table 5.15 presents the results of this model. It seems that the physical presence of historical legal capacity is quite relevant for productive outcomes and has important spillover effects over the neighbors in some cases. How these externalities operate are not explored in this stage of our work, but we presume that distance to legal capacity represents the broad access costs to judicial services.

\section{6}

\section{Exploring mechanisms}

This last section explores preliminary mechanisms that help understand how differences in legal capacity affected the mentioned firms' development indicators. First, in order to shed light on firms' restrictions, we use firm-level information related to perceptions about the state administration. This helps us understand how legal capacity impact on potential obstacles that firms experienced. Table 5.16 shows that municipalities with legal capacity have loosened financial frictions. Places with colonial legal capacity institutions have fewer difficulties to access to formal credit markets than places where legal capacity was not present. Also, those places have less demand for informal credit compared to other municipalities without those colonial institutions.

This initial result shed light on the heterogeneous evolution of informal norms caused by the existence of colonial legal institutions. Those places without legal capacity had to rely more on informal arrangements to obtain funds for investments than places with legal capacity. Again, our treated municipalities have fewer difficulties to obtain credit because banks have fewer costs to access judicial services. Then, the interaction with legal state services is more intense in our treated municipalities as a result of the persistent presence of state institutions in many dimensions of people's life. Our findings in this step are in line with the literature on how courts congestion ((43)) or quality of courts $((35))$ affect firms' size through its effect on loosening financial frictions. However, we need stronger evidence on these channels to make conclusive statements. 
Finally, we perform a placebo exercise by comparing the quality of the service of issuing licenses for the operation of commercial establishments, in places with and without colonial legal capacity. This specific service is provided by the local government as a public service representing the fiscal capacity dimension of the state. The results show that there is not a significant difference in the access to this broad state service. 


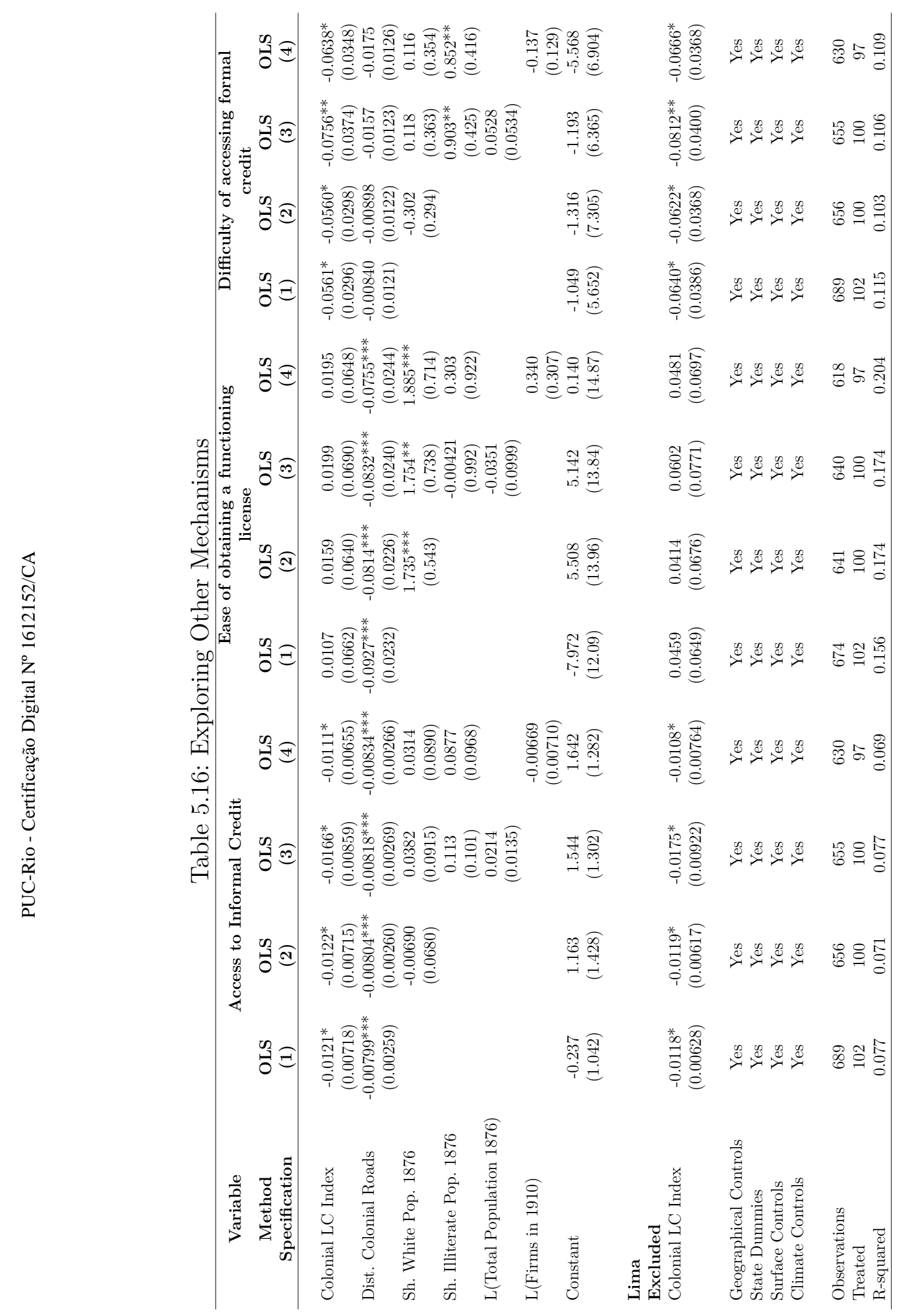




\section{6}

\section{Conclusions}

Our research has deepened in the connection between how state capacity affects social welfare. Here, we focused on the relationship between the legal capacity of the state and firms. This topic has attracted little attention from the recent literature on institutions and state capacity. We shed light on two important questions on the link between legal capacity and firms. First, we showed that there exist persistent effects of colonial legal capacity on five measures of firms' development and structure for two points in time. We rely on historical accounts to justify that the factors that explain where the Spaniards located their new settlements, and their legal State institutions, are no longer relevant to explain the features of firms development today. Furthermore, we showed that there exist many other municipalities that appear to be good controls.

We found that those places where Spaniards chose to create settlements and legal institutions are the ones where firms have better performance indicators. First, firms interchange more between each other using the market instead of adopting vertical structures. This represents a more efficient use of resources within the firms. Second, we evaluated the firms- size and sales per worker indicators. Firms are more developed in treated municipalities. Then, we expand the evidence on the link between the enforcement of legal institutions and the development of firms. For all our indicators, courts seem to be a quite important dimension. This last results complement existing evidence on the relative importance of State institutions, legal institutions are central for one side of economic development, firms.

All our results were robust to the addition of critical controls that test important theories verified by literature. Moreover, we estimate our model in subsamples to evaluate whether the observed results are driven by big cities or not. In fact, our estimates are quite stable to the estimation in subsamples. Also, we may suspect that one economic sector is driving the effects observed. However, we estimated a sector-municipality level with sectoral dummies and found that the results are common across sectors. Finally, we tested alternative model specifications, two IV models, and one network model, to evaluate the 
robustness of our result. In all the models we obtained similar results. All the tests performed, gave us confidence on the importance of our results.

For the second question, we analyzed the effect of colonial legal institutions to current legal institutions. Historical legal capacity is persistent over time because it changed the relative cost of subsequent investments in State capacity, specifically legal capacity, across the territory. We trace down in time the spatial distribution of courts and showed that colonial courts are good predictors of the current location of courts. These results help us explain the mechanisms through which colonial legal institutions continue to influence the distribution of firms in the space. However, this question would be answered in a broader sense for a future version of this work.

Third, we present preliminary results on the mechanisms that drove our results. Firms in municipalities with legal capacity exhibit less financial frictions and rely less on informal credit. These first results suggest that informal and formal rules evolve differently in places with and without historical state presence. Furthermore, the costs of access to legal capacity-related services seem to be important. People in our treated municipalities had a more intense relationship with the State through time than other places. On the other hand, a placebo exercise that compares the quality of a "fiscal capacity" related service in treated and non treated municipalities, did not find a significant difference. As a whole, our work is a valuable contribution on a specific mechanism on the relationship between state capacity and social welfare. 


\section{Bibliography}

[1] ACEMOGLU, D.. Politics and economics in weak and strong states. Journal of monetary Economics, 52(7):1199-1226, 2005.

[2] ACEMOGLU, D.; JOHNSON, S.. Unbundling institutions. Journal of political Economy, 113(5):949-995, 2005.

[3] ACEMOGLU, D.; GARCIA-JIMENO, C. ; ROBINSON, J. A.. State capacity and economic development: A network approach. The American Economic Review, 105(8):2364-2409, 2015.

[4] ACEMOGLU, D.; MOSCONA, J. ; ROBINSON, J. A.. State capacity and american technology: evidence from the nineteenth century. The American Economic Review, 106(5):61-67, 2016.

[5] ACEMOGLU, D.; ROBINSON, J. A.. The emergence of weak, despotic and inclusive states. Working Paper No. 23657, National Bureau of Economic Research, 2017.

[6] AGHION, P.; PERSSON, T. ; ROUZET, D.. Education and military rivalry. Working Paper No. 18049, National Bureau of Economic Research, 2012.

[7] ACEMOGLU, D.; JOHNSON, S. ; MITTON, T.. Determinants of vertical integration: finance, contracts, and regulation. Working Paper No. 11424, National Bureau of Economic Research, 2005.

[8] ACEMOGLU, D.; ROBINSON, J. A.. The emergence of weak, despotic and inclusive states. Working Paper No. 23657, National Bureau of Economic Research, 2017.

[9] AlesinA, A.; BAQIR, R. ; EASTERLY, W.. Public goods and ethnic divisions. The Quarterly Journal of Economics, 114(4):1243-1284, 1999.

[10] BANERJEE, A.; IYER, L.. History, institutions, and economic performance: The legacy of colonial land tenure systems in india. American economic review, 95(4):1190-1213, 2005. 
[11] BASADRE, J.. Historia de la República del Perú, volumen 10. Ediciones" Historia,", Lima, 1961.

[12] BECKER, S. O.; BOECKH, K.; HAINZ, C. ; WOESSMANN, L.. The empire is dead, long live the empire! long-run persistence of trust and corruption in the bureaucracy. The Economic Journal, 126(590):4074, 2016.

[13] BESLEY, T.. Property rights and investment incentives: Theory and evidence from ghana. Journal of Political Economy, 103(5):903-937, 1995.

[14] CABRAL, L.; MATA, J.. On the evolution of the firm size distribution: Facts and theory. The American Economic Review, 93(4):10751090, 2003.

[15] CONTRERAS, C.. Centralismo y descentralismo en la historia del Perú independiente. Osaka, Lima, 2000.

[16] CONTRERAS, C.. El impuesto de la contribución personal en el perú del siglo xix. historica, 29(2):67-106, 2005.

[17] CONTRERAS, C.. Menos plata pero más papas: consecuencias económicas de la independencia en el perú. Histórica, 35(2):101-132, 2011.

[18] CONTRERAS, C.; GLAVE, L. M. ; OTHERS. La independencia del perú. ¿ concedida, conseguida, concebida? Libros de otras Editoriales, 2015.

[19] DELL, M.. The persistent effects of peru's mining mita. Econometrica, 78(6):1863-1903, 2010.

[20] DELL, M.; LANE, N. ; QUERUBIN, P.. State capacity, local governance, and economic development in vietnam. Working paper, National Bureau of Economic Research, 2015.

[21] DE SOTO, H.; OTHERS. The other path. Harper \& Row, New York, 1989.

[22] DE SOTO, H.. The mystery of capital: Why capitalism triumphs in the West and fails everywhere else. Basic Civitas Books, 2000.

[23] DJANKOV, S.; LA PORTA, R.; LOPEZ-DE SILANES, F. ; SHLEIFER, A.. Courts. The Quarterly Journal of Economics, 118(2):453-517, 2003. 
[24] DEMSETZ, H.. Toward a theory of property rights. The American economic review, 57(2):347-359, 1967.

[25] ESPINOZA, W.. Virreinato peruano. Biblioteca Básica Peruana, Lima, 1997.

[26] GLAESER, E. L.; SHLEIFER, A.. Legal origins. The Quarterly Journal of Economics, 117(4):1193-1229, 2002.

[27] GLAESER, E. L.; LA PORTA, R.; LOPEZ-DE SILANES, F. ; SHLEIFER, A.. Do institutions cause growth? Journal of economic Growth, 9(3):271303, 2004.

[28] GENNAIOLI, N.; RAINER, I.. The modern impact of precolonial centralization in africa. Journal of Economic Growth, 12(3):185, 2007.

[29] GENNAIOLI, N.; VOTH, H.-J.. State capacity and military conflict. The Review of Economic Studies, 82(4):1409-1448, 2015.

[30] GUTIERREZ, S. A.. Historia y vicisitudes de un cabildo. Technical report, Tercer Congreso de la Asociación Iberoamericana de Academias de Historia. Academia Panameña de la Historia, 1993.

[31] HANKE, L.. La lucha por la justicia en la conquista de América, volumen 5. Istmo, 1988.

[32] JACOBSEN, N.. Mirages of Transition: The Peruvian Altiplano, 1780-1930. Univ of California Press, 1993.

[33] JOHNSON, S.; MCMILLAN, J. ; WOODRUFF, C.. Courts and relational contracts. Journal of Law, Economics, and organization, 18(1):221-277, 2002.

[34] LAVIANA CUeTOS, M. L.. Perú y Charcas, 1700-1760. Ediciones Rialp, 1983.

[35] LAEVEN, L.; WOODRUFF, C.. The quality of the legal system, firm ownership, and firm size. The Review of Economics and Statistics, 89(4):601-614, 2007.

[36] MIGUEL, E.; GUGERTY, M. K.. Ethnic diversity, social sanctions, and public goods in kenya. Journal of public Economics, 89(1112):2325-2368, 2005. 
[37] MILGROM, P.; ROBERTS, J.. An economic approach to influence activities in organizations. American Journal of sociology, 94:S154S179, 1988.

[38] MOORE, J. P.. The Cabildo in Peru Under the Hapsburgs;. Duke University Press, 1954.

[39] NARITOMI, J.; SOARES, R. R. ; ASSUNÇÃO, J. J.. Institutional development and colonial heritage within brazil. The journal of economic history, 72(2):393-422, 2012.

[40] NUNN, N.. Religious conversion in colonial africa. American Economic Review, 100(2):147-52, 2010.

[41] OSCAR, C. B.. Historia del derecho indiano. Tirant lo Blanch, Valencia, 2012.

[42] PERSSON, T.; BESLEY, T.. The origins of state capacity: Property rights, taxation and policy. The American Economic Review, 99(4):1218-1244, 2009.

[43] PONTICELLI, J.; ALENCAR, L. S.. Court enforcement, bank loans, and firm investment: evidence from a bankruptcy reform in brazil. The Quarterly Journal of Economics, 131(3):1365-1413, 2016.

[44] PORTA, R. L.; LOPEZ-DE SILANES, F.; SHLEIFER, A. ; VISHNY, R. W.. Law and finance. Journal of political economy, 106(6):1113-1155, 1998.

[45] NOEJOVICH, H.; SALAZAR-SOLES, C.; SUAREZ, M.; GLAVE, L. ; SALAS, M.. Compendio de historia económica del Perú II: la economía del período colonial temprano. BCRP and IEP, Lima, 2009.

[46] ROCHA, R.; FERRAZ, C. ; SOARES, R. R.. Human capital persistence and development. American Economic Journal: Applied Economics, 2017.

[47] SERNA, R. R.. Libro primero de cabildos de la ciudad del Cuzco, volumen 1. Universidad Nacional Mayor de San Marcos, 1965.

[48] TROUNSTINE, J.. Segregation and inequality in public goods. American Journal of Political Science, 60(3):709-725, 2016.

[49] DEL PINO, U.. Reseña histórica del origen y evolución de la justicia de paz en el perú. en temas peruanos: La justicia de paz y el pueblo. Centro de Investigaciones Judiciales de la Corte suprema de la República y Fundación Friedrich Naumann, 1987. 
[50] ULYSSEA, G.; OTHERS. Firms, informality and development: Theory and evidence from brazil. American Economic Review, 2014.

[51] URTEAGA, H. H.. La organización judicial en el imperio de los incas y en la colonia:(contribución al estudio del derecho peruano), volumen 25. Librería e imprenta Gil, SA, 1938.

[52] WANTCHEKON, L.; KLAŠNJA, M. ; NOVTA, N.. Education and human capital externalities: evidence from colonial benin. The Quarterly Journal of Economics, 130(2):703-757, 2014. 


\section{A}

\section{Published paper}

The following paper was published ... 